\title{
Serotonin in Aging, Late-Life Depression, and Alzheimer's Disease: The Emerging Role of Functional Imaging
}

Carolyn Cidis Meltzer, M.D., Gwenn Smith, Ph.D., Steven T. DeKosky, M.D., Bruce G. Pollock, M.D., Ph.D., Chester A. Mathis, Ph.D., Robert Y. Moore, M.D., Ph.D., David J. Kupfer, M.D., and Charles F. Reynolds, III, M.D.

Serotonin (5-HT) neuron and neurotransmitter loss in normal aging and neuropsychiatric diseases of late life may contribute to behavioral changes commonly observed in the elderly population. Extensive evidence implicates a deficit in serotonergic neurotransmission in the development of major depression. It has been further suggested that the agerelated changes in 5-HT neurons may predispose the elderly to develop depression. There is also increasing evidence that a combination of disturbances in cholinergic and serotonergic function may play a role in cognitive impairment in Alzheimer's disease $(A D)$, with serotonergic dysfunction potentially responsible for a significant portion of the behavioral aspects of the disease. This implication of the 5-HT system in aging and age-related cognitive and mood disorders rests in large part on post mortem studies and animal models, which are limited in their capacity to predict dynamic human biochemical-behavior relationships or to accurately model the living human brain. Initial applications of functional brian imaging with positron emission tomography (PET) in the in vivo study of the brain in aging, depression, and dementia focused on characterizing alterations in physiological measurements of cerebral metabolism and perfusion. However, recent advances in PET radiochemistry, instrumentation, and image processing have paved the way for noninvasive means to test specific hypotheses regarding the direct involvement of 5-HT neurons in the behavioral features of aging and to define and monitor therapeutic regimens for neuropsychiatric conditions of late life. Coupling of clinical trials in well-characterized subject populations with PET imaging using ligands specific for 5-HT receptor subtypes and transporter proteins promises to increase our understanding of the role of the 5-HT system in affective and cognitive aspects of treatment response. Longitudinal studies in aging, late-life depression, and $A D$ are also needed to evaluate the complex interplay between neurodegenerative processes and serotonergic neurotransmission. [Neuropsychopharmacology 18:407-430, 1998] (C) 1998 American College of Neuropsychopharmacology. Published by Elsevier Science Inc.
KEY WORDS: Serotonin; Receptors; Alzheimer's disease; Depression; Aging; Emission computed tomography

From the MHCRC for Late-Life Mood Disorders, Alzheimer's Disease Research Center, and the Functional Brain Imaging Research Program, University of Pittsburgh Medical Center, Pittsburgh, Pennsylvania.

Address correspondence to: Carolyn Cidis Meltzer, M.D., University of Pittsburgh Medical Center, PET Facility, B-938, 200 Lothrop Street, Pittsburgh, PA 15213-2582.

Received March 6, 1997; accepted October 3, 1997.
Major depression in late life and Alzheimer's disease (AD) are disorders of enormous and increasing public health significance. The prevalence of major depression is estimated at $1 \%$ to $10 \%$ of persons 60 years of age or older, whereas depressive symptoms may occur in up to 20\% (Blazer et al. 1987; Borson et al. 1986; Casey 1994). Substantially higher rates of both major and minor depressions occur among institutionalized aged persons (Parmelee et al. 1989). Furthermore, the rate of suicide in this age group is higher than at any other 
stage of life (Casey 1994). Psychosocial issues such as bereavement, disability, and declining health may serve as contributing factors in the development of geriatric depression (Casey 1994; Gilewski et al. 1991; Kennedy et al. 1991). Ad is truly a disorder of aging, with an incidence of $5 \%$ in persons older than 65 years and doubling of disease prevalence every 5 years after age 65; affected individuals represent $20 \%$ to $50 \%$ of the population after age 80 (Cross and Gurland 1986) (Evans et al. 1989). Costs associated with dementia burden exceed $\$ 90$ billion annually in the United States (Ernst and Hay 1994). Depression is commonly seen in AD patients and may further interfere with cognitive function, as well as substantially impact on the quality of life for both patients and caregivers (Alexopoulos and Abrams 1991; Fitz and Teri 1994; Shuttleworth et al. 1987).

The relationship between dementia and depression in late life is incompletely understood and probably complex. A total of $10 \%$ to $20 \%$ of elderly depressives have evidence of significant cognitive dysfunction, which may be reversible ("pseudodementia") (Kral and Emery 1989; Reynolds et al. 1986). A favorable response to treatment is associated with a predominance of depressive symptomatology relative to cognitive disturbance at presentation (Reynolds et al. 1986). Further, depression may be the initial sign of neurodegenerative disease and thus may be regarded as a risk factor for later development of dementia. Elderly depressed patients with cognitive impairment that improves with treatment carry a nearly five-fold increased chance of developing an irreversible dementia in the future when compared to age-matched patients with depression alone (Alexopoulos et al. 1993). An epidemiological study of community-living elders found that depressed mood was associated with a moderately increased risk of dementia, particularly AD (Devanand et al. 1996). Also, depression and AD may be coexisting disorders. Depression, which may have a tendency to occur in the earlier stages of AD (Fisher et al. 1990), complicates AD in an estimated $10 \%$ to $30 \%$ of patients (Komahashi et al. 1994; Teri and Reifler 1987). The frequency with which depression and dementia coexist in the elderly suggests an etiological link between the two conditions.

Our concept of the nature of the interaction between cognitive impairment and mood dysregulation in the elderly is evolving, with increasing interest in the influence of age- and disease-related changed on the integrity of the central 5-HT system. Whether the serotonergic profile of late-life depression is similar to that of early AD is not clearly defined, although this information would have significant implications for furthering our understanding of the relationship between depression and dementia. The evidence for serotonergic dysfunction in depression is based on the post mortem examination of brain tissue for 5-HT metabolite and receptor concentrations, the neuroendocrine response to serotonergic challenge, and the observation that the primary mode of action of antidepressants is by the alteration of 5-HT neurotransmission. In AD, post mortem studies and animal models of cholinergic hypofunction have demonstrated impairment of 5-HT systems. Although crucial to improving our understanding of the underlaying pharmacology involved in aging and mood and cognitive dysfunction, animal models; peripheral measures of 5-HT receptors, 5-HT, and 5-HT metabolites; and neuroendocrine challenge studies are indirect approaches to characterizing the functional state of human central 5-HT systems.

Our knowledge of the role of the 5-HT system in depression and AD has been confined by the limitations inherent in assays of autopsy material and peripheral 5-HT markers (Tables 1-3). Post mortem studies are limited to a single time point at the end stage of a disease process. Interpretation of post mortem findings is hindered by differences across studies in subject selection bias, post mortem delay, agonal state of the patient, tissue preparation, and exposure to psychotropic medications. Animal models of depression and AD only mimic some aspects of the human disorder. Neuroendocrine measures are complex and may be influenced by an array of pathophysiological processes. Nonetheless, these studies have played an important role in directing neurobiological hypotheses regarding the pathophysiology of depression and the overlap between late-life depression and AD.

Tables 1-3-Major findings from published post mortem, platelet binding, and imaging studies of aging, depression, and AD for the 5-HT2A receptor (Table 1), 5-HT1A receptor (Table 2), and 5-HT transporter/reuptake site (Table 3 ) are presented in Tables 1-3. Reports of significant increases $(\uparrow)$, significant decreases $(\downarrow)$, and the lack of a significant change $(\leftrightarrow)$ in regional binding are listed. Where multiple brain region(s) were examined, only those associated with the main findings are specified in parenthesis. These tables do not necessarily provide a complete account of all brain regions evaluated in each study.

One of the more promising approaches to furthering our understanding of the relationship between depression and dementia is through in vivo functional imaging of the 5-HT neurotransmitter system with positron emission tomography (PET). Previous PET studies used tracers for flow and metabolism to identify the landscape of functional deficits in aging, depression, and AD. Such studies served as the foundation to guide current and future work to determine the neurochemical bases of these changes. The purpose of this review is to evaluate the 5-HT neurotransmitter system as a substrate for the functional deficits and clinical symptomatology observed in aging, late-life depression, and AD. An overview of the anatomy of the 5-HT system, and a review of animal model, human postmortem, and in 
Table 1. Summary of Literature Findings on $5-\mathrm{HT}_{2 \mathrm{~A}}$ Binding Sites in Aging, Depression, and $\mathrm{AD}$

\begin{tabular}{|c|c|c|}
\hline & & Comments/Limitations \\
\hline \multicolumn{3}{|l|}{ Aging } \\
\hline \multicolumn{3}{|l|}{ Post mortem } \\
\hline Marcusson et al. 1984a,b & $\downarrow$ (frontal) & cross-reactivity of spiperone to dopamine receptors \\
\hline Cheetham et al. 1988 & $\downarrow$ (frontal, occipital) & \\
\hline Sparks 1989 & $\downarrow$ (frontal) & cross-reactivity of spiperone to dopamine receptors \\
\hline Gross-Isseroff et al. 1990 & $\downarrow$ (hippocampus) & \\
\hline Arranz et al. 1993 & $\downarrow$ (frontal) & \\
\hline \multicolumn{3}{|l|}{ Platelets } \\
\hline Biegon and Greuner 1992 & $\downarrow \%$ & $\begin{array}{l}\text { children and adolescents only studied; \% decreased in } \\
\text { adolescence }\end{array}$ \\
\hline McBride et al. 1994 & $\downarrow$ & \\
\hline \multicolumn{3}{|l|}{$P E T / S P E C T$} \\
\hline Wong et al. 1984 & $\downarrow$ (frontal) & cross-reactivity of spiperone to dopamine receptors \\
\hline Iyo and Yamasaki 1993 & $\downarrow$ (frontal) & cross-reactivity of spiperone to dopamine receptors \\
\hline Blin et al. 1993 & $\begin{array}{l}\downarrow \text { (frontal, temporal, parietal, } \\
\quad \text { occipital) }\end{array}$ & \\
\hline \multicolumn{3}{|l|}{ Depression } \\
\hline \multicolumn{3}{|l|}{ Post mortem } \\
\hline Owen et al. 1983 & $\leftrightarrow$ & suicide victims and depressives \\
\hline Crow et al. 1984 & $\leftrightarrow$ & $\begin{array}{l}\text { elderly depressives plus partially characterized suicide victims; } \\
\text { recent antidepressant use }\end{array}$ \\
\hline Owen et al. 1986 & $\leftrightarrow$ & $\begin{array}{l}\text { frontal lobe only examined; uncharacterized suicide victims; } \\
\text { recent antidepressant exposure }\end{array}$ \\
\hline Cheetham et al. 1988 & $\downarrow$ (hippocampus only) $^{\mathrm{a}}$ & \\
\hline Arora and Meltzer 1989a,b & $\uparrow$ (frontal) & $\begin{array}{l}\text { uncharacterized suicide victims } \\
\text { (no difference between violent vs. non-violent means) }\end{array}$ \\
\hline Bowen et al. 1989 & $\downarrow$ (frontal, temporal, parietal) & elderly depressives; small sample size \\
\hline Arango et al. 1990 & $\uparrow$ (prefrontal) & uncharacterized suicide victims \\
\hline Gross-Isseroff et al. 1990 & $\downarrow$ (prefrontal, hippocampus) & uncharacterized suicide victims \\
\hline Hrdina et al. 1993 & $\uparrow$ (prefrontal, amygdala) & mixed unipolar/bipolar suicide victims; antidepressant-free \\
\hline Stockmeier et al. 1996 & $\leftrightarrow$ (prefrontal, hippocampus) & suicide victims with documented major depression \\
\hline \multicolumn{3}{|r|}{ 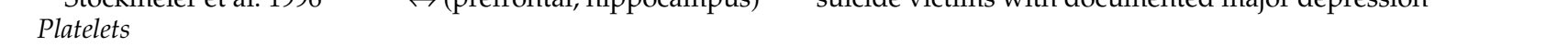 } \\
\hline McBride et al. 1994 & $\leftrightarrow$ platelet binding & \\
\hline \multicolumn{3}{|l|}{$P E T / S P E C T$} \\
\hline D’haenen et al. 1992 & $\begin{array}{l}\uparrow(\text { parietal }) \\
\mathrm{R} / \mathrm{L} \text { frontal asymmetry }\end{array}$ & SPECT \\
\hline \multicolumn{3}{|c|}{ 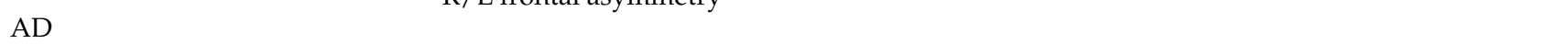 } \\
\hline \multicolumn{3}{|l|}{ Post mortem } \\
\hline Cross et al. 1984 & $\begin{array}{l}\downarrow \text { (frontal, temporal, cingulate, } \\
\quad \text { amygdala) }\end{array}$ & \\
\hline Crow et al. 1984 & $\begin{array}{l}\downarrow \text { (frontal, temporal, cingulate, } \\
\quad \text { amygdala) }\end{array}$ & \\
\hline Reynolds et al. 1984 & $\downarrow$ (frontal) & \\
\hline Sparks 1989 & $\downarrow$ (frontal) & cross-reactivity of spiperone to dopamine receptors \\
\hline Bowen et al. 1989 & $\downarrow$ (frontal, temporal, parietal) & \\
\hline Dewar et al. 1990 & $\leftrightarrow$ (frontal, hippocampus) & recent psychotropic medication use \\
\hline Jansen et al. 1990 & $\downarrow$ (hippocampus) & \\
\hline Cheng et al. 1991 & $\downarrow$ (temporal) & recent psychotropic medication use \\
\hline Proctor et al. 1992 & $\leftrightarrow^{\mathrm{b}}$ & small sample size \\
\hline \multicolumn{3}{|l|}{ PET/SPECT } \\
\hline Blin et al. 1993 & $\begin{array}{l}\downarrow \text { (frontal, temporal, parietal, } \\
\quad \text { occipital) }\end{array}$ & moderately to severely demented \\
\hline
\end{tabular}

${ }^{a}$ Only seen in anti-depressant-free subgroup.

${ }^{\mathrm{b}}$ Patients without aggressive symptoms.

vivo data implicating 5-HT in these conditions is presented. We also outline the potential use of PET and new 5-HT radioligands as a vehicle to assess the preand postsynaptic integrity of the 5-HT system and to test hypotheses generated by preclinical data, neuroen- docrine studies, and post mortem work. Finally, we define the potential for future PET studies, combined with randomized clinical trails, to identify predictors of treatment response and treatment resistance with the goal of guiding future drug development. 
Table 2. Summary of Literature Findings on 5- $\mathrm{HT}_{1 \mathrm{~A}}$ Binding Sites in Aging, Depression, and AD

Comments/Limitations

\begin{tabular}{|c|c|}
\hline \multicolumn{2}{|l|}{ Aging } \\
\hline \multicolumn{2}{|l|}{ Post mortem } \\
\hline Shih and Young 1978 & $\downarrow$ \\
\hline Bowen et al. 1983 & $\downarrow$ (frontal) \\
\hline Marcusson et al. 1984 & $\downarrow$ (frontal, hippocampus) \\
\hline Middlemiss et al. 1986 & $\downarrow$ (temporal) \\
\hline Sparks 1989 & $\downarrow$ (frontal) $^{\mathrm{a}}$ \\
\hline Dillon et al. 1991 & $\downarrow$ (frontal, hippocampus, raphe) $^{\mathrm{b}}$ \\
\hline Matsubara et al. 1991 & $\downarrow$ (frontal) $)^{\mathrm{c}}$ \\
\hline Arranz et al. 1993 & $\leftrightarrow($ frontal $)$ \\
\hline \multicolumn{2}{|l|}{ Depression } \\
\hline \multicolumn{2}{|l|}{ Post mortem } \\
\hline Crow et al. 1984 & $\leftrightarrow$ \\
\hline Owen et al. 1986 & $\leftrightarrow$ \\
\hline Bowen et al. 1989 & $\leftrightarrow$ \\
\hline Matsubara et al. 1991 & $\uparrow(\text { frontal })^{\mathrm{d}}$ \\
\hline Francis et al. 1993 & $\downarrow$ (frontal) [biopsy] \\
\hline Arango et al. 1995 & $\uparrow$ (most marked prefrontal) \\
\hline Stockmeier et al. 1996 & $\leftrightarrow$ (prefrontal, hippocampus) \\
\hline \multicolumn{2}{|l|}{$\mathrm{AD}$} \\
\hline \multicolumn{2}{|l|}{ Post mortem } \\
\hline Bowen et al. 1983 & $\downarrow$ (frontal) \\
\hline Cross et al. 1984 & $\begin{array}{l}\downarrow \text { (temporal, hippocampus, } \\
\quad \text { amygdala) }\end{array}$ \\
\hline Crow et al. 1984 & $\begin{array}{l}\downarrow \text { (temporal, hippocampus, } \\
\quad \text { amygdala) }\end{array}$ \\
\hline Middlemiss et al. 1986 & $\downarrow$ (frontal) \\
\hline Palmer et al. 1987a & $\downarrow$ (frontal) \\
\hline Bowen et al. 1989 & $\downarrow$ (frontal, temporal, parietal) \\
\hline Sparks 1989 & $\leftrightarrow($ frontal $)$ \\
\hline Francis et al. 1993 & $\downarrow$ (frontal) [biopsy] \\
\hline
\end{tabular}

Aging

Marcusson et al. 1984

Matsubara et al. 1991

Aression

ost mortem

Crow et al. 1984

$\downarrow$ (frontal) [biopsy] cross-reactivity of 5HT for other receptor subtypes cross-reactivity of $5 \mathrm{HT}$ for other receptor subtypes cross-reactivity of $5 \mathrm{HT}$ for other receptor subtypes

cross-reactivity of $5 \mathrm{HT}$ for other receptor subtypes

elderly depressives plus partially characterized suicide victims; recent antidepressant use; cross-reactivity of 5HT for other receptor subtypes

frontal lobe only examined; uncharacterized suicide victims; recent antidepressant exposure

elderly depressives; small $n$

recent antidepressant exposure; mixed unipolar/bipolar; small sample size

uncharacterized suicide victims

suicide victims with documented major depression

cross-reactivity of 5HT for other receptor subtypes

cross-reactivity of 5HT for other receptor subtypes

most subjects not medication-free

cross-reactivity of 5HT for other receptor subtypes

${ }^{\text {a }}$ Limited age interval (5th-6th decade).

${ }^{\mathrm{b}}$ In males only.

${ }^{\mathrm{c}}$ In males only.

${ }^{\mathrm{d}}$ Nonviolent suicides only.

\section{ANATOMY OF THE SEROTONIN SYSTEM}

The 5-HT systems are widespread throughout the brain, with most of the cell bodies of serotonergic neurons located in the raphe nuclei of the midline brainstem (Palacios et al. 1990). There are two systems of 5-HT neurons in the brainstem raphe characterized by the location of their cell bodies and the areas that they innervate (Tork 1990). The largest collections of 5-HT neurons are in the dorsal and median raphe nuclei of the caudal midbrain (Jacobs and Azmitia 1992). The neurons of these nuclei project widely over the thalamus, hypothalamus, basal ganglia, basal forebrain, and the entire neocortex. Interestingly, these 5-HT neurons also provide a dense subependymal plexus throughout the lateral and third ventricles. Activation of this innervation results in 5-HT release into the cerebrospinal fluid (CSF), and measurement of 5-HT content in CSF in disease states will largely reflect this pool (Chan-Palay 1976). This is another interesting aspect of the 5-HT neuron innervation of forebrain. Work by Descarries and colleagues (Descarries et al. 1975) has shown that the terminals of 5-HT neurons in forebrain, unlike terminals from other systems, only infrequently form synaptic complexes. Thus, when 5-HT neurons innervating forebrain are activated, 5-HT will be released into the extracellular fluid, and its action will depend on the location of nearby 5-HT receptors (Figure 1). The organization of the ascending 5-HT neuron projections, the nature of their interaction with postsynaptic elements, and the widespread distribution of 5-HT terminals in cortical and limbic areas indicate that these projections are most likely to be involved in the regulation of behavioral state and the modulation of more specific behaviors. The second 5-HT neuron system is comprised of 5-HT neurons in the pontine and medullary raphe with pro- 
Table 3. Summary of Literature Findings on 5-HT Transporter/Reuptake Binding Sites in Aging, Depression, and AD

Comments/Limitations

\begin{tabular}{|c|c|}
\hline Aging & \\
\hline Post mortem & \\
\hline Owen et al. 1986 & $\uparrow$ (hippocampus, occipital) \\
\hline Marcusson et al. 1987 & $\downarrow$ (cingulate only) \\
\hline Andersson et al. 1992 & $\leftrightarrow$ (cingulate, amygdala $)$ \\
\hline Arranz et al. 1993 & $\leftrightarrow($ frontal $)$ \\
\hline Depression & \\
\hline Post mortem & \\
\hline Stanley et al. 1982 & $\downarrow$ (frontal) \\
\hline Perry et al. 1983 & $\downarrow$ (occipital, hippocampus) \\
\hline Bowen et al. 1983 & $\downarrow$ (temporal) \\
\hline Arora and Meltzer 1989a,b & $\leftrightarrow($ frontal $)$ \\
\hline Lawrence et al. 1990 & $\leftrightarrow$ (many cortical regions) \\
\hline Leake et al. 1991 & $\downarrow$ (frontal) \\
\hline Hrdina et al. 1993 & $\leftrightarrow$ (prefrontal, amygdala) \\
\hline Arango et al. 1995 & $\downarrow$ (most marked prefrontal) \\
\hline Platelets & \\
\hline Briley et al. 1980 & $\downarrow$ platelet binding \\
\hline Paul et al. 1981 & $\downarrow$ platelet binding \\
\hline Ellis et al. 1992 & $\downarrow$ platelet binding \\
\hline $\mathrm{AD}$ & \\
\hline Post mortem & \\
\hline Perry et al. 1983 & $\leftrightarrow$ \\
\hline D'Amato et al. 1987 & $\downarrow$ (frontal) \\
\hline Marcusson et al. 1987 & $\downarrow$ (cingulate, putamen) \\
\hline Tejani-Butt et al. 1995 & $\downarrow$ (dorsal raaphe, hippocampus) \\
\hline Chen et al. 1996 & $\downarrow\left(\right.$ temporal), $\leftrightarrow$ (frontal $^{\mathrm{a}}$ \\
\hline Platelets & \\
\hline Arora et al. 1991 & $\uparrow$ uptake of $5 \mathrm{HT}$ into platelets ${ }^{\mathrm{b}}$ \\
\hline Andersson et al. 1991 & $\leftrightarrow$ \\
\hline Inestrosa et al. 1993 & $\downarrow$ uptake of 5HT into platelets \\
\hline Koren et al. 1993 & $\downarrow$ uptake of $5 \mathrm{HT}$ into platelets \\
\hline
\end{tabular}

lack of specificity of imipramine for transporter

uncharacterized suicide victims; lack of specificity of imipramine for transporter

varied medication exposure; lack of specificity of imipramine for transporter

lack of specificity of imipramine for transporter uncharacterized suicide victims

high specificity paroxetine used; premortem diagnosis of depression; antidepressant-free recent antidepressant exposure

mixed unipolar/bipolar suicide victims; antidepressant-free

uncharacterized suicide victims

lack of specificity of imipramine for transporter lack of specificity of imipramine for transporter lack of specificity of imipramine for transporter

lack of specificity of imipramine for transporter lack of specificity of imipramine for transporter

high specificity paroxetine used

a Both temporal and frontal $\downarrow$ in depressed AD.

${ }^{\mathrm{b}}$ Mild/moderate AD, trend toward $\downarrow$ in severe AD.

jections principally to brainstem, cerebellum, and spinal cord. This system appears primarily to be involved in modulation of sensory input and motor control.

Serotonin receptors have been classified into families designated $5-\mathrm{HT}_{1-7}$ on the basis of their molecular biological characteristics (Hoyer and Martin 1997; Peroutka 1994; Saudou and Hen 1994). At present these have been subdivided into approximately 14 subtypes, and their number grows each year. $\mathrm{Th}^{5}-\mathrm{HT}_{1 \mathrm{~B} / \mathrm{D}}$ receptors are found largely presynaptically, the $5-\mathrm{HT}_{1 \mathrm{~A}}$ receptor exists in both a presynaptic and postsynaptic form, and the remaining receptor subtypes are expressed predominately postsynaptically with their distribution and density regulated with respect to individual brain area and functional state. Another protein important in serotonergic neurotransmission is the 5-HT transporter. This protein is localized on the membrane of 5-HT nerve terminals and is responsible for reuptake of released 5-HT into the terminals. The distribution of the 5-HT transporter conforms closely to the distribution of 5-HT nerve terminals (Dawson and Wamseley 1983; Fuxe et al. 1983), and thus may serve as a marker for the integrity of serotonergic projections. The $5-\mathrm{HT}_{1 \mathrm{~A}}$ and $5-\mathrm{HT}_{2 \mathrm{~A}}$ receptors and the 5-HT reuptake site are the most frequently targeted sites of action for antidepressant medications and have been well-characterized physiologically. Thus, these sites have also been the focus of radiochemistry development.

Evidence from animal and human studies suggest that 5-HT is linked to many functions, such as mood, aggression, feeding, and sleep. Dysregulation of 5-HT function is believed to be involved in depression, impulsivity, and suicide (Arango et al. 1992; Kennett 1991; Meltzer 1990; Staner et al. 1992). Additionally, modulation of cholinergic neuronal activity by 5-HT may play a role in higher cognitive processes such as memory and 


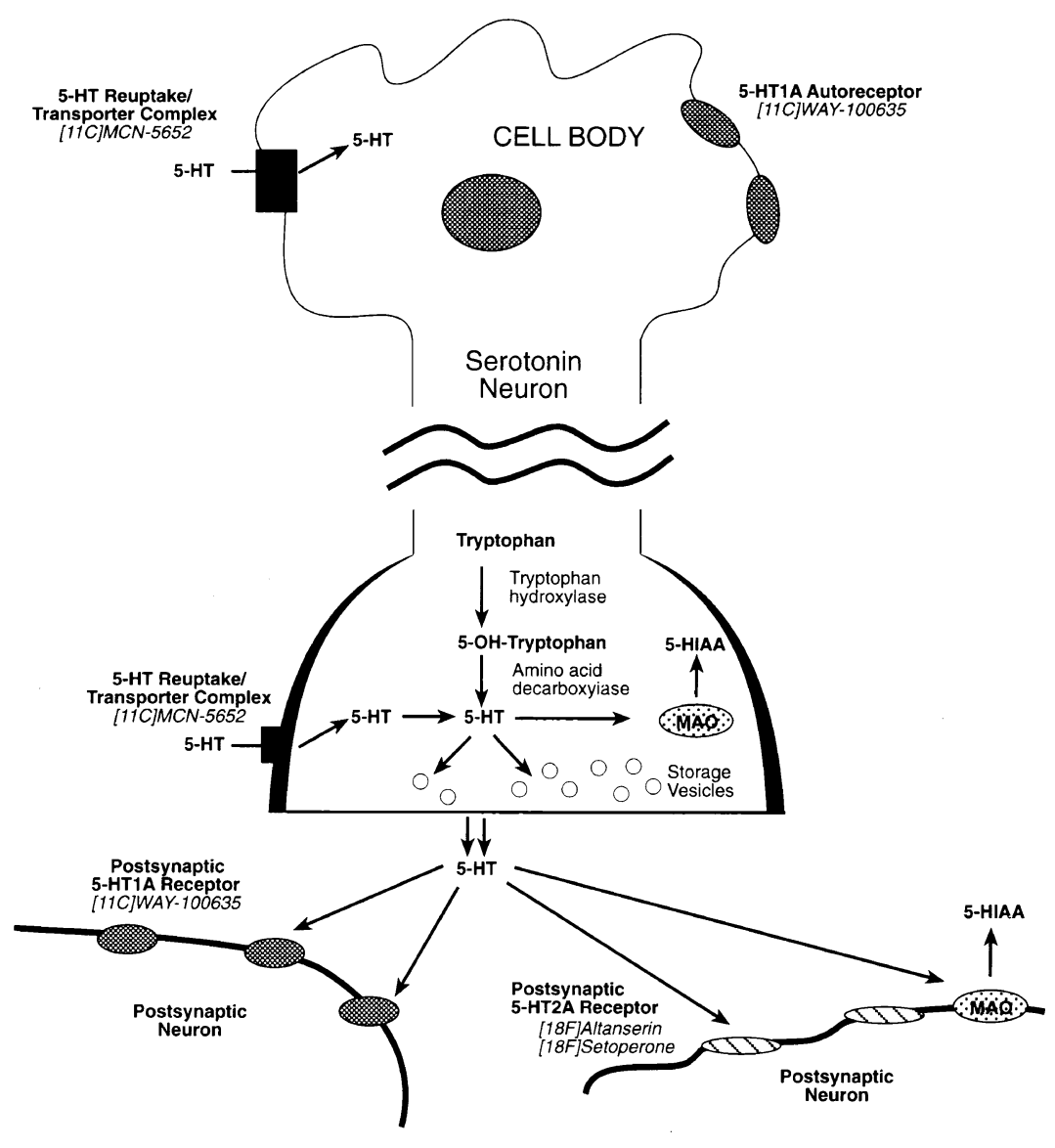

Figure 1. Schematic representation of 5-HT neuron showing sites of action of several PET radiotracers (italics). learning (Altman et al. 1990; Carli et al. 1992; RichterLevin and Segal 1990; Riekkinen et al. 1994). Accordingly, alterations in serotonergic function may account for behavioral disturbances commonly observed in the elderly. Indeed, changes in serotonergic activity have been implicated in normal aging, depression, and dementia; however, there is conflicting evidence from animal studies, post mortem work, and limited clinical trails as to the direction, magnitude, and significance of these findings. The purpose of this review is to examine the areas of agreement and remaining controversies regarding the 5-HT system in late-life neuropsychiatric disorders and further to explore the promise of newer tools, such as PET, to address unresolved questions that may be the clinical and therapeutic importance.

\section{AGING AND SEROTONIN}

There are limited and conflicting data in the literature regarding changes in the 5-HT system in normal aging. Serotonin receptors are more dense at birth than in the mature brain and may regulate the maturation of cortical neurons (Azmitia and Whitaker-Azmitia 1991). Although no age effect on the binding or affinity of $\left[{ }^{3} \mathrm{H}\right]$ ketanserin to cortical $5-\mathrm{HT}_{2 \mathrm{~A}}$ receptors or $\left[{ }^{3} \mathrm{H}\right] 8$-hydroxy-2-(di- n-propylamino)tetralin $\left(\left[{ }^{3} \mathrm{H}\right] 8-\mathrm{OH}-\mathrm{DPAT}\right)$ to $5-\mathrm{HT}_{1 \mathrm{~A}}$ receptors has been demonstrated in rats (Robson et al. 1993; Yamaguchi and Yamagata 1991), several post mortem human studies have reported a reduction in the number of cortical 5- $\mathrm{HT}_{1 \mathrm{~A}}, 5-\mathrm{HT}_{1 \mathrm{~B} / \mathrm{D}}$, and $5-\mathrm{HT}_{2 \mathrm{~A}}$ binding sites with age in frontal lobe, occipital lobe, and hippocampus (Arranz et al. 1993; Cheetham et al. 1988; Gross-Isseroff et al. 1990; Marcusson et al. 1984a,b; Shih and Young 1978; Sparks 1989) (Tables 1 and 2). Agerelated decline in cortical $5-\mathrm{HT}_{2 \mathrm{~A}}$ binding in living healthy subjects is supported by PET imaging with $\left[{ }^{11} \mathrm{C}\right] \mathrm{N}$-methylspiperone, a ligand with affinity for both 5- $\mathrm{HT}_{2 \mathrm{~A}}$ and dopamine $\mathrm{D}_{2}$ receptors (Iyo and Yamasaki 1993; Wong et al. 1984). Also, both aging and postmenopausal decreases in estrogen levels may contribute to alterations in circulating 5-HT and central 5- $\mathrm{HT}_{1 \mathrm{~A}}$ and $5-\mathrm{HT}_{2 \mathrm{~A}}$ receptors densities in women (Biver et al. 1996; Frankfurt et al. 1994; Gonzales and Carillo 1993; Zhang et al. 1994). A decline in 5-HT function with aging is consistent with observations of age-related changes in behaviors, such as sleep, that are linked to serotonergic function (DeKosky and Palmer 1994; Myers and Badia 1995; Sharpley et al. 1994).

There is scant literature on the effect of aging on the 5-HT transporter, and the available reports are inconsistent (Table 3). Although the rat 5-HT system appears to 
remain intact throughout the life span, a $65 \%$ decrease in $\left[{ }^{3} \mathrm{H}\right]$ imipramine binding has been demonstrated in cortical membrane fractions from Suncus murinus, an insectivore with a shorter life span than the rat that has been proposed as a mammalian animal model of the aging brain (Yamaguchi and Yamagata 1991). In humans, Marcusson et al. (1987) demonstrated a 50\% decline in $\left[{ }^{3} \mathrm{H}\right]$ imipramine binding in the cingulate with aging, but found no influence of age in the frontal cortex, hippocampus, amygdala, and basal ganglia. Reports by Andersson et al. (1992) and Arranz et al. (1993) failed to demonstrate an age effect on the 5-HT transporter in human post mortem cortical specimens using $\left[{ }^{3} \mathrm{H}\right]$ paroxetine, a more highly selective radioligand. Thus, in humans, the absence of alteration in reuptake site number indicates that the 5-HT axonal plexus in cortex is intact in normal aging. However, age-related decline in postsynaptic receptors has been reported more consistently. As some of these receptor sites are associated with other neurotransmitter systems altered by the aging process (e.g., 5- $\mathrm{HT}_{1 \mathrm{~A}}$ receptors associated with cholinergic terminals), this may reflect pathology secondary to other neurochemical deficits.

\section{SEROTONIN IN LATE-LIFE DEPRESSION}

Major depression in later life has unique implications in terms of prognosis, treatment options, and possibly etiological mechanisms relative to depression occurring in young or mid-life adults. Geriatric depression carries an increased risk of suicide, higher morality, and the potential for future development of dementia (Casey 1994: McGuire and Rabins 1994; Reynolds et al. 1986). Lateage onset of depression appears to be a risk factor for treatment failure and chronicity (Alexopoulos et al. 1996). Treatment issues are also complicated by the diminished tolerance of side effects in the elderly and potential interactions between antidepressants and other medications. The association of structural brain changes, such as cortical atrophy and white matter lesions, and vascular risk factors, with late-life and particularly lateonset depression, suggests an interaction between aging and biological factors in depression occurring in the elderly (Alexopoulos et al. 1992; Baldwin and Tomenson 1995; Figiel et al. 1991). The well-recognized vasomotor effects of 5-HT (Wiernsperger 1990), limited evidence for serotonergic control of the regulation of cerebral blood flow (McBean et al. 1990, 1991), and the potential influence of age on both of these factors (Hajdu et al. 1993) support the existence of a link, although as yet illdefined, between disturbances in serotonergic function and risk of cerebral ischemia. Interestingly, Husain et al. (1991) found an inverse correlation between platelet $\left[{ }^{3} \mathrm{H}\right]$ imipramine binding and white matter hyperintensities in a group of elderly depressed subjects. Thus, al- though the mechanism is unclear, potential alterations in 5-HT neurotransmission that occur as part of normal aging may be an important factor in predisposing the elderly to develop depression.

The serotonergic hypothesis of depression holds that 5-HT dysregulation is central to the pathophysiology of mood disorders. This is based on considerable evidence that a disturbance in central serotonergic activity is a major etiological factor in depression (Cowen 1993; Engleman et al. 1992; Maes and Meltzer 1995). There is a notable overlap between behaviors frequently disturbed in depression (e.g., sleep) and those linked to 5-HT. Depletion of plasma levels of tryptophan, a precursor for 5-HT synthesis, has been associated with depressive relapse in patients previously successfully treated with antidepressants (Delgado et al. 1990). Serotonin neuroendocrine studies in depressive illness have shown a blunted prolactin response to the 5-HT-releasing agent d-fenfluramine, which is mediated by the $5-\mathrm{HT}_{2 \mathrm{~A}}$ receptor (Cowen 1993). Differences in slow-wave sleep pattern response to the $5-\mathrm{HT}_{2 \mathrm{~A}}$ antagonist ritanserin between depressed patients and controls have also been reported (Staner et al. 1992). Post mortem studies demonstrated increased $5-\mathrm{HT}_{2 \mathrm{~A}}$ receptors in the prefrontal cortex of suicide victims and depressed persons who died of natural causes (Arango et al. 1990; Arora and Meltzer 1989b; Hrdina et al. 1993; Stanley and Mann 1983), consistent with the hypothesis that $5-\mathrm{HT}_{2 \mathrm{~A}}$ receptors up-regulate in response to a defect in serotonergic neurotransmission. Indeed, preclinical studies provide evidence to suggest that the mechanism of action of tricyclic antidepressant medications is sensitization of postsynaptic 5- $\mathrm{HT}_{2 \mathrm{~A}}$ receptors to 5-HT (Blier et al. 1990). Similarly, animal and human studies suggest that the therapeutic effect of electroconvulsive therapy (ECT) in depression is linked to enhanced neuronal responsiveness to 5-HT (de Montigny 1984; Shapira et al. 1992). And, the clinical effectiveness of selective 5-HT reuptake inhibitors (SSRIs) is believed to be mediated through enhancement of extracellular 5-HT (Blier et al. 1990). However, some groups have found no differences in 5- $\mathrm{HT}_{2 \mathrm{~A}}$ binding between depressed suicide victims and controls (Cheetham et al. 1988; Owen et al. 1986). These data are consistent with a recent post mortem autoradiographic study restricted to suicide victims with documented major depression during the last month of life. In this study, Stockmeier et al. (1996) found no difference between controls and suicide victims in $\left[{ }^{3} \mathrm{H}\right]$ ketanserin binding to $5-\mathrm{HT}_{2 \mathrm{~A}}$ receptors in the right prefrontal cortex and hippocampus.

Differences in factors that may affect $5-\mathrm{HT}_{2 \mathrm{~A}}$ binding, such as post mortem delay, tissue preparation, selectivity of markers for specific receptor subtypes, subject selection bias, and prior antidepressant therapy may account for some of the variability in reported findings among post mortem studies of 5-HT receptor status 
(Table 1). Many antidepressant medications may have mixed agonist and antagonist properties. Therefore, heterogeneity of the effects of antidepressants on the $5-\mathrm{HT}_{2 \mathrm{~A}}$ receptor may account for some of the contradictory reports on the directionality of observed changes in the $5-\mathrm{HT}_{2 \mathrm{~A}}$ receptor in depression. Paradoxical downregulation in response to a variety of $5-\mathrm{HT}_{2 \mathrm{~A}}$ antagonists has been observed in ex vivo studies of this receptor subtype (Leysen 1990), although up-regulation recently has been demonstrated using highly selective $5-\mathrm{HT}_{2 \mathrm{~A}}$ antagonists (Rinaldi-Carmona et al. 1993). Selection of the brain regions examined may vary from study to study, and thus makes interpretation of this body of literature particularly difficult. Also, receptor assays performed using homogenates of large brain sections would be less likely than autoradiographic techniques to uncover small but potentially important regional variations in receptor number. The inherent bias of the post mortem literature toward study of mid-life suicide victims, often poorly characterized clinically, and the paucity of data on the 5-HT system in depression of late life underscores the need for further investigation in this area.

There is limited, yet increasing, evidence for $5-\mathrm{HT}_{1 \mathrm{~A}}$ receptor dysfunction in depression (Table 2). It is inconclusive, based on binding studies in human and animal tissue, whether alterations in $5-\mathrm{HT}_{1 \mathrm{~A}}$ receptor density exist in depression. Using a learned helplessness rat model of depression, Edwards et al. (1991) found no change in $5-\mathrm{HT}_{1 \mathrm{~A}}$ receptor number in the cortex, hippocampus, and septum. However, human post mortem data by Arango et al. (1995) showed an inverse relationship between increases in $5-\mathrm{HT}_{1 \mathrm{~A}}$ and decreases in 5-HT reuptake site binding in the prefrontal cortex of suicide victims. Matsubara et al. (1991) curiously found up-regulation $5-\mathrm{HT}_{1 \mathrm{~A}}$ sites to be limited to nonviolent suicides. In elderly depressives, a lack of alteration in $5-\mathrm{HT}_{1 \mathrm{~A}}$ binding sites in post mortem frontal, temporal, and parietal tissue has been reported (Bowen et al. 1989). The antidepressant potential of 5- $\mathrm{HT}_{1 \mathrm{~A}}$ agonists further suggests that this 5-HT receptor subtype is involved in the anxiolytic and other therapeutic effects of antidepressant medications. In animal models, agonists of the $5-\mathrm{HT}_{1 \mathrm{~A}}$ receptor have been shown to produce an antidepressant response through mediation of postsynaptic binding sites, possibly through alteration of second messenger transduction (Kostowski et al. 1992; Luscombe et al. 1993; Newman et al. 1992). The results of limited clinical trials also support a significant role of the $5-\mathrm{HT}_{1 \mathrm{~A}}$ receptor in depression (Robinson et al. 1990).

The 5-HT reuptake site/transporter complex has been a recent focus of animal and human investigations of depression. In the learned helplessness rat model, changes in $\left[{ }^{3} \mathrm{H}\right]$ paroxetine binding to 5 -HT reuptake sites have been demonstrated in the hippocampus and hypothalamus (Edwards et al. 1991). Jaffe et al. (1993) demonstrated a significant decrease in 5-HT release from brain slices taken from the hippocampus, prefrontal cortex, and nucleus accumbens in two rat models of depression. Tissue content of 5-HT was also reduced. Alterations in $\left[{ }^{3} \mathrm{H}\right]$ imipramine binding to the $5-\mathrm{HT}$ reuptake site on human platelets have been associated with depressed states (Briley et al. 1980; Paul et al. 1981); however, Ellis et al. (1992) were unable to find a clear relationship between recovery from depression and $\left[{ }^{3} \mathrm{H}\right]$ imipramine platelet binding. Human post mortem studies have failed to clarify whether the 5-HT reuptake site is altered in depression (Table 3). Reductions in $\left[{ }^{3} \mathrm{H}\right]$ imipramine binding have been demonstrated in the frontal cortex of suicide victims (Stanley et al. 1982) and in the occipital cortex and hippocampus in depressives (Perry et al. 1983), whereas others have found no differences between suicide/depressed and controls (Arora and Meltzer 1989a). Again, this discrepancy may be due to methodologic factors and issues of subject selection, such as whether the suicide had been accomplished by violent or nonviolent means. Also, a disadvantage of the tricyclic antidepressant imipramine is the large proportion of binding attributed to sites other than the 5-HT reuptake site (Hrdina et al. 1990). Using $\left[{ }^{3} \mathrm{H}\right]$ paroxetine, a more selective marker for the 5-HT reuptake site, Lawrence et al. (1990) found no difference in binding between depressed suicides and controls. Hrdina et al. (1993) similarly reported no alternation in presynaptic 5-HT reuptake sites measured with $\left[{ }^{3} \mathrm{H}\right]$ paroxetine between suicide/depressives and control subjects; however, the ratio of postsynaptic $5-\mathrm{HT}_{2 \mathrm{~A}}$ receptor and presynaptic 5-HT reuptake sites was increased in the amygdala, suggesting an imbalance between serotonergic activity and receptor number.

The 5-HT reuptake site may be of particular importance in the treatment of depression. The capability of ECT to elicit a rapid and lasting increase in the number of 5-HT reuptake sites in the rat frontal cortex has been demonstrated (Hayakawa et al. 1995). The clinical efficacy of SSRIs further suggests responsiveness of the 5-HT reuptake site to regulation by antidepressant therapies. Kovachich et al. (1992) showed variable effects of repeated administration of several antidepressants, including SSRIs, monoamine oxidase (MAO) inhibitors; and the atypical antidepressant agent mianserin on $[3 \mathrm{H}] \mathrm{cy}-$ anoimipramine binding to the 5-HT reuptake site in the limbic system and parietal cortex of rats. Examining changes in 5-HT reuptake site occupancy through the course of treatment for depression may potentially provide information on therapeutic mechanisms and indicators of treatment success and prognosis.

Although there is considerable evident that 5-HT dysregulation is a critical component of the neurobiology of depression, it is unclear whether the fundamental defect is in the presynaptic element, the postsynaptic element, or a combination of the two. Further, the extent to which the 5-HT system is influenced by age and 
age-related factors such as cerebrovascular disease is a matter of controversy. Indeed, it is not known whether a predilection for depression expressed as the capacity for developing dysregulation of 5-HT neurotransmission is a component of depression in the elderly.

\section{SEROTONERGIC DYSFUNCTION IN ALZHEIMER'S DISEASE}

Although marked cholinergic dysfunction in AD is well documented, treatments targeting the cholinergic system alone have yielded disappointing results. Previous post mortem studies in AD have most consistently implicated a presynaptic cholinergic deficit, and the strength of these findings led to a cholinergic hypothesis of memory dysfunction and AD (Davies and Maloney 1976; DeKosky et al. 1985; Perry et al. 1978; Whitehouse et al. 1985). A clear relationship between the cognitive and behavioral symptomatology in AD and deficits in the cholinergic and other neurotransmitter systems has not yet been established; however, there is considerable evidence in the post mortem literature supporting direct involvement of the 5-HT system (Tables 1-3). First, reduction of 5-HT and its metabolites have been reported in post mortem AD brains (Reinikainen et al. 1990). In the temporal cortex, 5-HT reuptake sites are depleted to a similar extent as 5-HT and metabolites in patients with early $\mathrm{AD}$, suggesting a loss of serotonergic nerve terminals (Cross 1990) (Table 3). Second, the raphe nucleus, and area of high serotonergic neuronal density, is a preferential site for neurofibrillary tangle (NFT) formation and neuronal losses in AD (Curcio and Kemper 1984). Finally, there is evidence of decreases in cortical 5-HT receptors, with 5- $\mathrm{HT}_{2 \mathrm{~A}}$ preferentially affected over $5-\mathrm{HT}_{1 \mathrm{~A}}$ receptors (Cheng et al. 1991; Cross 1990). It is important to note that the $5-\mathrm{HT}_{2 \mathrm{~A}}$ receptor is associated with cholinergic nerve terminals in the cerebral cortex and hippocampus (Quirion et al. 1985). Serotonergic dysfunction in AD appears to reflect a selective process rather than the result of generalized cortical neuronal degeneration, because other neurotransmitter systems, such as opioid, $\gamma$-aminobutyric acid (GABA), $\alpha-1, \alpha-2$, and $\beta$-adrenergic, are unaltered or less severely affected (Bowen et al. 1983; Cross 1990; Nordberg 1992).

The relationship between the loss of 5-HT receptors in the cortex and loss of brain stem serotonergic neurons in AD is not entirely clear. Both pre- and postsynaptic disturbances in the 5-HT system have been reported in AD (Bowen et al. 1983; D'Amato et al. 1987; Halliday et al. 1992; Marcusson et al. 1987; Palmer et al. 1987a; Sparks et al. 1986; Tejani-Butt et al. 1995); however, there is conflicting evidence as to whether serotonergic pathology arises from a defect of isodendritic core or reflects a process of primary cortical degeneration. Reduced uptake of $\left[{ }^{3} \mathrm{H}\right] 5-\mathrm{HT}$ into tissue prisms of biopsy samples from the frontal and temporal cortex AD patients suggests an early change in the serotonergic nerve terminal (Bowen et al. 1983). There is no comparable data on the integrity of the 5-HT cell bodies in the brainstem raphe in early AD. Sparks et al. (1986) reported decreased $\left[{ }^{3} \mathrm{H}\right]$ spiperone binding to $5-\mathrm{HT}_{2 \mathrm{~A}}$ and dopamine $\mathrm{D}_{2}$ receptors, as well as reduced levels of 5-HT, in the nucleus basalis of Meynert (nbM) in AD brian homogenates. One possible explanation for this finding is degeneration of serotonergic afferents to the $\mathrm{nbM}$ from the dorsal raphe. Indeed, markers of presynaptic serotonergic dysfunction have been documented in post mortem tissue from the dorsal raphe, hippocampus, and cortex of AD patients (Bowen et al. 1983; D'Amato et al. 1987; Halliday et al. 1992; Marcusson et al. 1987; Palmer et al. 1987a; Tejani-Butt et al. 1995). However, the pattern of preferential serotonergic depletion in the temporal and parietal cortex and hippocampus favors a disease pathogenesis of cortical degeneration with retrograde degeneration of ascending 5-HT pathways (Palmer et al. 1987b). Palmer et al. (1987b) among others have argued that primary involvement of the brain stem with selective loss of certain ascending projections would be less likely. This proposed mechanism is consistent with a report of neuritic plaques and NFTs in the cortex and hippocampus appearing at a younger age than the pathological changes in the dorsal raphe nucleus in Down's syndrome patients, who are predisposed to the early development of $\mathrm{AD}$ (Mann et al. 1984). Although the 5-HT system lacks a clear topographical relationship between brain stem nuclei and cortical projections, the spatial pattern of cell loss in other neurotransmitter systems such as the noradrenergic system, further suggests a primary process of cortical degeneration in AD (Burke et al. 1988; German et al. 1987; Marcyniuk et al. 1986).

The age of disease presentation appears to be an important determinant of the profile of neurochemical deficits in AD. DeKosky et al. (1985) found an agerelated decline in activity of the cholinergic synthetic enzyme choline acetyltransferase (CAT) in autopsied frontal lobe in controls, whereas a positive correlation between age and CAT was observed in specimens from AD brains. They calculated that no difference in frontal cortex CAT would be observed between AD patients and age-matched control subjects beyond age 75. Arai et al. (1992) also found more severe depletions of CAT and of 5-HT and its primary metabolite 5-hydroxyindoleacetic acid (5-HIAA) in early-onset than late-onset AD brains. Similarly, although reductions of several 5-HT receptor subtypes have been reported in normal aging, there is an inverse relationship between age and $\left[{ }^{3} \mathrm{H}\right] 5-\mathrm{HT}$ binding in AD patients, with similar levels in controls and AD subjects reached at approximately 85 years of age (Bowen et al. 1983). These data suggest that 
serotonergic dysfunction may be most prominent in $\mathrm{AD}$ patients with an earlier onset of disease, and further, that age-associated and AD changes are different but both are degenerative and potentially additive.

Peripheral 5-HT markers are limited in their ability to characterize the primary locus of serotonergic dysfunction in $\mathrm{AD}$. Although platelet $5-\mathrm{HT}_{2 \mathrm{~A}}$ measurements are recognized to potentially reflect changes in brain 5- $\mathrm{HT}_{2 \mathrm{~A}}$ receptor density, platelet binding of $\left[{ }^{3} \mathrm{H}\right]$ paroxetine (a high affinity marker for the 5-HT reuptake site) has not been found to be a useful in vivo indicator of alterations in the central 5-HT transporter in $\mathrm{AD}$ (Andersson et al. 1992). In contrast to the blunted prolactin response observed in depressed patients, $\mathrm{AD}$ patients exhibit an exaggerated d-fenfluramine-induced prolactin effect (McLoughlin et al. 1994). Loss of inhibitory cholinergic influence may be responsible for functionally abnormal responses to probes of the 5-HT system.

Memory function if variably affected in healthy elderly individuals (Craik and Jennings 1992; Rapp and Amaral 1992), and it has been postulated that 5-HT may play an important role in age-related memory impairment. This theory is supported by work by Strosznajder et al. (1994), who demonstrated aging to diminish the stimulatory effect of 5-HT on arachidonic acid uptake into membrane lipids, a mechanism believed to be important in memory processing. The importance of the hippocampus in memory processes is well known. It is, therefore, not surprising that this structure commonly undergoes early atrophic changes in AD and has been closely linked to the basis of the memory dysfunction in this disorder (Denys et al. 1992; Erkinjuntti et al. 1993; Zola-Morgan, et al. 1992). The aging effects of increased 5-HT turnover and morphological changes in serotonergic afferents in the hippocampus have been demonstrated in rats and may reflect serotonergic neuronal degeneration (Venero et al. 1993). Because of the high density of postsynaptic $5-\mathrm{HT}_{1 \mathrm{~A}}$ receptors in the hippocampus-where they have been shown to be associated with cholinergic terminals-reductions of $5-\mathrm{HT}_{1 \mathrm{~A}}$ binding may serve as a specific marker for cholinergic neuron loss. Indeed, although age-dependent decreases in hippocampal 5- $\mathrm{HT}_{1 \mathrm{~A}}$ receptors have been observed in post mortem human brain (Dillon et al. 1991; Marcusson et al. 1984b), $5-\mathrm{HT}_{1 \mathrm{~A}}$ receptor density in the hippocampus in $\mathrm{AD}$ is reduced to only $60 \%$ of that of normal age-matched controls (Cross et al. 1984).

Both memory-enhancing effects and deterioration of memory function have been linked to serotonergic activity. Altman et al. (1984) demonstrated dose-dependent facilitation of memory retrieval in mice with the 5-HT reuptake blockers alaproclate and zimeldine. However, this group later showed rats performed better in a spatial discrimination task following selective neurotoxic (5, 7-DHT) deafferentation of 5-HT input to the hippocampus (Altman et al. 1990). Serotonin most likely affects memory by modulation of other neurotransmitter systems, especially the cholinergic system, an effect potentially mediated by $5-\mathrm{HT}_{1 \mathrm{~A}}, 5-\mathrm{HT}_{2 \mathrm{~A}}$, and $5-\mathrm{HT}_{3 \mathrm{~A}}$, receptors (Barnes et al. 1989; Costall et al. 1990; Quirion and Richard 1987; Vizi et al. 1981). Robinson (1983) demonstrated that a focal lesion in the dorsal raphe nucleus of the rat resulted in decreased 5-HT content and increased acetylcholine turnover in the hippocampus and cortex. Facilitation of memory has been reported in rats treated with ketanserin, a $5-\mathrm{HT}_{2 \mathrm{~A}}$ receptor antagonist, and the acetlycholinesterase inhibitor physostigmine (Normile and Altman 1992). This effect was observed at lower doses than required to produce a similar effect then each drug was administered alone. Additionally, the mixed 5-HT agonist/antagonist m-chlorophenylpiperazine (m-CPP) administered with scopolamine augmented performance on cognitive measures as compared to scopolamine alone in healthy elderly subjects (Little et al. 1995). These data a support the finding of Richter-Levin and Segal (1990), who attributed cognitive deterioration in aged rats to the combination of impairments in both serotonergic and cholinergic function.

The question of whether deficits in 5-HT cell number and neurotransmission in AD is associated with the frequent coexistence of depression is unresolved (Alder et al. 1995; Zweig et al. 1995). However, serotonergic dysfunction appears to be closely linked to the behavioral aspects of AD (Golden et al. 1991; Gottfries 1990; Proctor et al. 1992). Chen et al. (1996), using $\left[{ }^{3} \mathrm{H}\right]$ paroxetine and autoradiography, showed a decrease in the 5-HT reuptake sites in the temporal but not frontal cortex of AD brains; significant decreases were found in both areas for those AD subjects who had persistent depressive symptoms. Crow et al. (1984) found a decrease in post mortem imipramine binding in only a small subgroup of AD patients with a history of depression, who had committed suicide. Similarly, diminished binding of paroxetine to orbitofrontal and temporal cortex 5-HT reuptake sites has been found in the brains of $\mathrm{AD}$ patients with prominent depressive symptoms in life (Chen et al. 1995). In addition to depressive symptomatology, other behavioral features of AD have been specifically linked to serotonergic dysfunction. Loss of 5-HT in the inferior frontal cortex was reported to be limited to AD patients with prominent aggressive behavior (Palmer et al. 1988). Psychosis has been associated with significant reductions in 5-HT and increased densities of senile plaques in the prosubiculum (Zubenko et al. 1991). Furthermore, agitated/delusional AD patients have shown significantly lower platelet 5-HT reuptake site binding densities than nonagitated patients or healthy elderly control subjects (Schneider et al. 1988). Thus, it appears that greater 5-HT deficits have been observed in AD patients with depressive symptoms and aggression.

Although there are currently no large, rigorously controlled studies of cognitive and behavioral responses of 
AD patients to serotonergic medications, preliminary evidence suggests that treatment regimens using selective 5-HT enhancing agents have primarily behavioral rather than cognitive effects in AD. When alaproclate, a highly specific 5-HT reuptake inhibitor, was administered to 12 hospitalized AD patients, clinical efficacy (increased coping ability and decreased aggressiveness and irritability) was demonstrated in five patients (Bergman et al. 1983). Similarly, citalopram administered to AD patients resulted in significant improvement in emotional blunting, confusion, anxiety, irritability, fear, depression, and motor restlessness, whereas no effect was observed in patients with multi-infarct dementia (Nyth and Gottfries 1990). Interestingly, increases in anergy and depression were reported by Lawlor et al. (1991) after administration of the 5-HT agonist meta-chlorophenylpiperazine ( $\mathrm{m}-\mathrm{CPP}$ ) to eight moderately to several affected $\mathrm{AD}$ patients. In nondemented elderly depressed patients, treatment with the SSRI paroxetine may result in improvements in both depressive symptoms and cognitive function (Schone and Ludwig 1993). Although the mechanism remains unclear, serotonergic dysfunction is probably of particular relevance to the noncognitive aspects of $\mathrm{AD}$, including depression, with important implications for the therapeutic intervention.

Although there is clear evidence for 5-HT disturbance in $\mathrm{AD}$, its pathophysiology and clinical significance are only partly defined. Interaction between the 5-HT and cholinergic system amy be important in memory loss in nondemented elderly persons and in the pathological memory disturbance of AD. However, both post mortem studies and clinical trails of medications that enhance serotonergic activity suggest a stronger association between 5-HT dysfunction and behavioral rather than cognitive symptomatology. The prominent feature of cortical neuropathology in AD is consistent with secondary retrograde degeneration of ascending serotonergic brainstem neurons, although this remains unproven. Further study using in vivo imaging techniques to examine both pre- and postsynaptic elements of the 5-HT system is needed to fully characterize the progression of 5-HT dysfunction throughout the course of the disease and assess its impact on practical issues of patient management and treatment options.

\section{FUNCTIONAL IMAGING IN AGING, DEPRESSION AND ALZHEIMER'S DISEASE}

Functional imaging techniques, including PET and single photon emission tomography (SPECT), permit in vivo characterization of regional blood flow, cerebral metabolism (PET only), neuroreceptor and transporter concentration, and neurotransmitter synthesis in normal aging and at both early and later stages of neuropsychiatric disease. Initial functional imaging studies in aging, depression, and dementia focused on determining regional disturbances of cerebral metabolism and perfusion. Such studies lacked neurotransmitter specificity information and usually did not account for the effects of cerebral atrophy on PET and SPECT data. The recent availability of selective PET radioligands for the 5-HT system and advances in PET instrumentation and methodology have opened the door to noninvasive investigation of serotonergic alterations in both normal aging and neuropsychiatric diseases of aging in the living human brain, with consideration of the effects of atrophy on the physiological signal. Whereas this review emphasizes functional brain imaging approaches, we acknowledge the potential importance of structural changes in the brain, such as cortical atrophy and white matter hyperintensities that can be characterized by the anatomical brain imaging methods of computed tomography $(\mathrm{CT})$ and magnetic resonance imaging (MRI).

At present, our understanding of how normal aging affects in vivo brain function is rudimentary. Whether there is an age-related decline in cerebral metabolic function is still unsettled. PET studies performed with $\left[{ }^{18} \mathrm{~F}\right]$ fluorodeoxyglucose (FDG) have variably found decrements in quantitative global and regional measurements of cerebral metabolic rate for glucose (CMRGlc) with aging (Kuhl et al. 1982; Loessner et al. 1995; Salmon et al. 1991; Yoshii et al. 1988). There also have been reports of widespread age-related reductions in regional cerebral perfusion and oxygen metabolism using PET (Martin et al. 1991; Takada et al. 1992). However, other investigators have shown a poor correlation between age and metabolic measures with PET (Burns and Tyrrell 1992; de Leon et al. 1983; Duara et al. 1984; Takada et al. 1992). The lack of consistency of these reported findings may be due, in part, to variability in scanner resolution and lack of correction for age-related cerebral volume loss. Another major variable among these studies is whether cases were selected for "successful aging," in which cognitive function is equal to that of much younger persons, or "usual aging," in which the commonly reported "normal" cognitive changes of aging are found.

Functional imaging studies have examined metabolic parameters in depressed patients, with reported reductions in regional cerebral blood flow (CBF) and CMRGlc in depression primarily in the frontal lobe and, less commonly, the temporal lobe (Baxter et al. 1989; Bench et al. 1992; Mayberg 1994). Regional increases in cerebral perfusion and metabolism have also been reported (Drevets et al. 1992, 1996). Changes in CBF and CMRGlc in unipolar and bipolar depressed patients localized to the cingulate, left prefrontal cortex, and left amygdala have been demonstrated to resolve with successful SSRI treatment (Drevets et al. 1992, 1996; Mayberg et al. 1996). Using [ ${ }^{99 \mathrm{~m}} \mathrm{Tc}$ ] hexamethylpropyleneamine oxime (HMPAO) SPECT, Bonne et al. 1996) noted 
an increase in CBF, most striking in the cingulate gyrus, in depressed patients who responded to ECT. Nonresponders showed no significant differences in regional CBF between pre- and post-ECT scans. Metabolic alterations in paralimbic frontal and temporal cortex have also been observed in patients with secondary depression associated with neurodegenerative disorders, such as Parkinson's disease and Huntington's disease (Mayberg 1994). Mayberg (1994) hypothesized that this finding may reflect may reflect disruption of paralimbic pathways common to major depression and depression associated with neurodegenerative disease. Furthermore, widespread cortical metabolic decrements of similar magnitude have been reported in AD and late-life depressed patients (Kumar et al. 1993).

The capability of PET and SPECT to provide noninvasive, in vivo metabolic and neurochemical measurements over the course of disease progression is a significant advantage over receptor binding assays of post mortem tissue. The ability to study the early stages of the disease process makes these imaging modalities especially powerful tools for the study of the pathogenesis of neurodegenerative disorders. Indeed, $\mathrm{AD}$ has been extensively studied with FDG PET, with most investigators reporting significant reductions in CMRGlc in the temporal and parietal lobes (Chawluk et al. 1985; Duara et al. 1986; Foster et al. 1984; Friedland et al. 1983; Jamieson et al. 1987; Nybäck et al. 1991; Polinsky et al. 1987). Frontal lobe hypometabolism has been variably found, particularly in severely affected patients (Chawluk et al. 1985; Cutler et al. 1985; Foster et al. 1984), with widespread cortical metabolic reductions observed in the later stages of disease (Cutler et al. 1985). A similar regional distribution of $\mathrm{CBF}$ abnormalities in $\mathrm{AD}$ has been reported using SPECT imaging (DeKosky et al. 1990; Frlich et al. 1989; Jagust et al. 1987, 1990). SPECT studies exhibiting a pattern of bilateral temporoparietal reduction in $\mathrm{CBF}$ have demonstrated the greatest clinical diagnostic utility in differentiating early $\mathrm{AD}$ from normal aging, MID, and Pick's disease, with both sensitivity and specificity approaching $90 \%$ (Bonte et al. 1986, 1990; Holman et al. 1991; Jagust et al. 1987). Additionally, strong correlations have been found between cognition and parietal cortical CBF ratios using SPECT (DeKosky et al. 1990). Further, alterations in CMRGlc have been recently reported in nondemented individuals who may be at increased risk for AD (Reiman et al. 1996; Small et al. 1995).

Despite the diagnostic utility of resting metabolic and perfusion measures, such studies reflect generalized physiological brain responses and reveal little of specific underlying biochemical defects. To probe the neurochemical correlate of glucose metabolic changes in depression, Mann et al. (1996) performed FDG PET before and after challenge with the serotonin-enhancing agent, fenfluramine. In this study, depressed subjects showed a blunted regional metabolic response to fenfluramine. This finding, which is consistent with the results of neuroendocrine studies, suggested involvement of 5-HT in the observed CMRGlc alterations in depressed patients. Experience with direct imaging of 5-HT receptors in depression is limited to a single report by $\mathrm{D}^{\prime}$ haenen et al. (1992), who demonstrated increased $5-\mathrm{HT}_{2 \mathrm{~A}}$ receptor binding with SPECT and $\left[{ }^{123} I\right]$ ketanserin in the parietal cortex only of depressed subjects compared to that of controls. The semiquantitative nature and lower resolution of SPECT relative to PET makes it a less desirable imaging modality for studying neuroreceptor systems.

\section{Limitations of PET: Effects of Image Resolution and Cerebral Atrophy}

Recent technical advances in PET imaging and data analysis have contributed greatly to the promise of PET for investigating dynamic neuroreceptor function in neurological and psychiatric disorders. However, despite significant improvements in scanner resolution over the past decade, functional PET studies remain substantially poorer in resolution relative to anatomic imaging techniques, such as CT or MRI. Underestimation of cortical activity due to partial volume averaging with surrounding structures having lower activity, such as expanded CSF spaces in cortical atrophy, is an important and recognized source of error in PET data, and one that may interfere with the comparison of subject groups with different magnitudes and regional distributions of cerebral volume loss. This potential limitation of PET is particularly relevant in quantitative imaging studies of elderly populations (Figure 2). A variable degree of cerebral atrophy accompanies the normal aging process (Albert et al. 1992; Coffey et al. 1992; Condon et al. 1986; Jernigan et al. 1990; Murphy et al. 1992) and brain atrophy is characteristically accelerated in $\mathrm{AD}$, particularly in temporal and frontal lobe regions (Jack et al. 1992; Seab et al. 1988; Shefer 1972; Terry et al. 1981). Also, several morphometric studies have suggested accentuated cerebral atrophic changes in late-life depressives relative to healthy elderly subjects (Alexopoulos et al. 1992; Beats et al. 1991; Kumar et al. 1994). Application of a regional MRI-based partial volume correction approach to FDG PET data did not completely account for metabolic differences between $\mathrm{AD}$ patients and age-matched healthy control subjects (Meltzer et al 1990, 1996). These data suggest that cerebral atrophy affects, but is not solely responsible for, observations of significant regional cortical hypometabolism in AD with PET. Further modifications of partial volume correction methodology include corrections for potential age- and disease-related changes in relative proportions of gray and white matter, and for dilution of radioactivity signal concentration in small subcortical structures due to a combination of recovery coeffi- 
cient and partial volume effects (Meltzer et al. 1995; Mueller-Gaertner et al. 1992). The application of MRIguided partial volume correction and improvements in the spatial resolution of newer PET tomographs will reduce or potentially eliminate the confounding effect of cerebral atrophy inherent in earlier comparisons of elderly subject groups with PET.

\section{PET Imaging of the Serotonin System}

Due to new advances in neuroreceptor ligand development, focused in vivo studies of central receptor function are now possible with PET. Selective PET markers of the 5-HT system have only recently been developed, with earlier ligands such as $\left[{ }^{11} \mathrm{C}\right]$ - or $\left[{ }^{18} \mathrm{~F}\right]$-labeled $\mathrm{N}$-methylspiperone suffering from cross-binding with dopamine receptors and low specific to nonspecific binding ratios (Frost 1990; Wong et al. 1984). A PET study of the 5-HT system in $\mathrm{AD}$ using $\left[{ }^{18} \mathrm{~F}\right]$ setoperone, a $5-\mathrm{HT}_{2 \mathrm{~A}}$ receptor ligand that also binds with moderate affinity to dopamine $\mathrm{D}_{2}$ receptors (Frost 1990), found large reductions in binding in the temporal (69\%), parietal (55\%), occipital $(35 \%)$, and frontal $(69 \%)$ lobes in the AD group and a significant age-related decline in age-matched controls (Blin et al. 1993). These data were not corrected for the potential underestimation of binding measures in the AD group due to cerebral atrophy. Recently, other selective 5-HT PET ligands have recently become available, including $\left[{ }^{18} \mathrm{~F}\right]$ altanserin, a more selective $5-\mathrm{HT}_{2 \mathrm{~A}}$ receptor ligand (Crouzel et al. 1992; Lemaire et al. 1991; Sadzot et al. 1995); $\left[{ }^{11} \mathrm{C}\right]$ WAY-100635, a 5-HT $1 \mathrm{~A}$ receptor marker (Mathis et al. 1994); and $\left[{ }^{11} \mathrm{C}\right] \mathrm{McN}-5652 \mathrm{X}$, a highly potent blocker of the 5-HT reuptake site (Suehiro et al. 1993a, b) (Figure 1). Although there are no PET ligands currently available for the $5-\mathrm{HT}_{1 \mathrm{~B} / \mathrm{D}}$ receptors, recent focus on characterizing this aspect of the 5-HT system may provide the basis for the future development of specific receptor ligands (Pauwels 1997). PET techniques have also been applied to the measurement of 5-HT synthetic rates in vivo (Diksic et al. 1991, 1995).

One of the first of these promising 5-HT radiotracers was $\left[{ }^{18} \mathrm{~F}\right]$ altanserin, a $5-\mathrm{HT}_{2 \mathrm{~A}}$ receptor antagonist. Dynamic PET brain imaging of $\left[{ }^{18} \mathrm{~F}\right]$ altanserin in animals and humans corresponded to the known distribution of $5-\mathrm{HT}_{2 \mathrm{~A}}$ receptors in human brain (Biver et al. 1994, 1997; Sadzot et al. 1995). Quantitative $\left[{ }^{18} \mathrm{~F}\right]$ altanserin PET studies conducted in baboons and normal human subjects at our institution have also demonstrated a radioactivity distribution paralleling that found with in vitro studies of the $5-\mathrm{HT}_{2 \mathrm{~A}}$ receptor and further have suggested a decrement in binding with increasing age (Figure 3). Other promising PET ligands for the $5-\mathrm{HT}_{2 \mathrm{~A}}$ receptor are $\left[{ }^{11} \mathrm{C}\right] \mathrm{MDL} 100907$ and $\left[{ }^{11} \mathrm{C}\right] \mathrm{SR}$ 46349B. $\left[{ }^{11} \mathrm{C}\right] \mathrm{MDL}$ 100907 has similar binding potency but greater specificity for the $5-\mathrm{HT}_{2 \mathrm{~A}}$ receptor as compared with $\left[{ }^{18} \mathrm{~F}\right] \mathrm{al}-$ tanserin (Lundkvist et al. 1996; Mathis et al. 1995, 1996).
A highly potent and specific $5-\mathrm{HT}_{2 \mathrm{~A}}$ receptor antagonist, $\left[{ }^{11} \mathrm{C}\right] \mathrm{SR} 46349 \mathrm{~B}$, has properties that suggest it may prove useful as a sensitive means to detect in vivo changes in endogenous 5-HT levels (Ashworth et al. 1996; Dewey et al. 1994).

The first potent and selective PET tracer for the 5- $\mathrm{HT}_{1 \mathrm{~A}}$ receptor is $\left[{ }^{11} \mathrm{C}\right] \mathrm{WAY}-100635$ (Hume et al. 1994; Mathis et al. 1994; Price et al. 1996). However, a radioactive metabolite of the O-methylated form of $\left[{ }^{11} \mathrm{C}\right]$ WAY100635 was found to interfere with tracer kinetic modeling and characterization of receptor binding behavior of the parent compound (Osman et al. 1996). The recent development of a carbonyl-labeled form of $\left[{ }^{11} \mathrm{C}\right] W A Y-$ 100635 has resulted in a superior $5-\mathrm{HT}_{1 \mathrm{~A}}$ receptor ligand with very high ratios of specific to nonspecific binding (Pike et al. 1996) (Figure 4). Radiotracers for both the $5-\mathrm{HT}_{2 \mathrm{~A}}$ and $5-\mathrm{HT}_{1 \mathrm{~A}}$ sites permit the imaging of cortical areas due to the relatively high concentrations of these receptor subtypes in the cortex. As there is a higher concentration of $5-\mathrm{HT}_{1 \mathrm{~A}}$ receptors in the mesial temporal lobe, compounds that bind to this site such as $\left[{ }^{11} \mathrm{C}\right]$ WAY-100635 permit the visualization of the hippocampal/amygdala complex. These regions may be especially important to evaluate in vivo due to the degenerative changes that occur in these regions in aging and $\mathrm{AD}$ and the involvement of these structures in functional imaging studies of depression.

Efforts to develop radiolabeled SSRIs and related compounds as PET ligands of the 5-HT transporter have been problematic (for review, see Fletcher et al. 1995). However, Szabo et al. (1995a) have performed qualitative and quantitative studies of presynaptic 5-HT function in humans using $\left[{ }^{11} \mathrm{C}\right] \mathrm{McN}-5652 \mathrm{X}$, the active (+)-enantiomer of $\left[{ }^{11} \mathrm{C}\right] \mathrm{McN}-5652$. This group was reported PET studies in humans and baboons showing regional localization of $\left[{ }^{11} \mathrm{C}\right] \mathrm{McN}-5652 \mathrm{X}$ binding that is both consistent with the known distribution of the 5-HT reuptake site and is reduced following blockage of specific binding sites with fluoxetine pretreatment (Szabo et al. 1995a, b). Preliminary PET imaging studies with $\left[{ }^{11} \mathrm{C}\right] \mathrm{McN}-5652 \mathrm{X}$ performed in baboons and humans at our institution have resulted in high tracer concentration in the brain stem region of the raphe nucleus, medium levels of uptake in the thalamus and cortex, and low activity in the cerebellum, a pattern consistent with the distribution of 5-HT reuptake sites as determined from in vivo studies (Figure 5).

Another aspect of 5-HT function that can be imaged with PET is 5-HT synthesis. Diksic and colleagues (Diksic et al. 1991, 1995; Nishizawa et al. 1997) have used radiolabeled $\alpha$-methyl-L-tryptophan ( $\alpha$-MTrp), a tryptophan analog, to track 5-HT synthesis in ex vivo and in vivo animal studies and, more recently, in vivo in humans. Acute treatment with fluoxetine, a 5-HT reuptake inhibitor, has been shown to markedly enhance 5-HT synthesis in the rat brain (Tsuiki et al. 1995b). This 


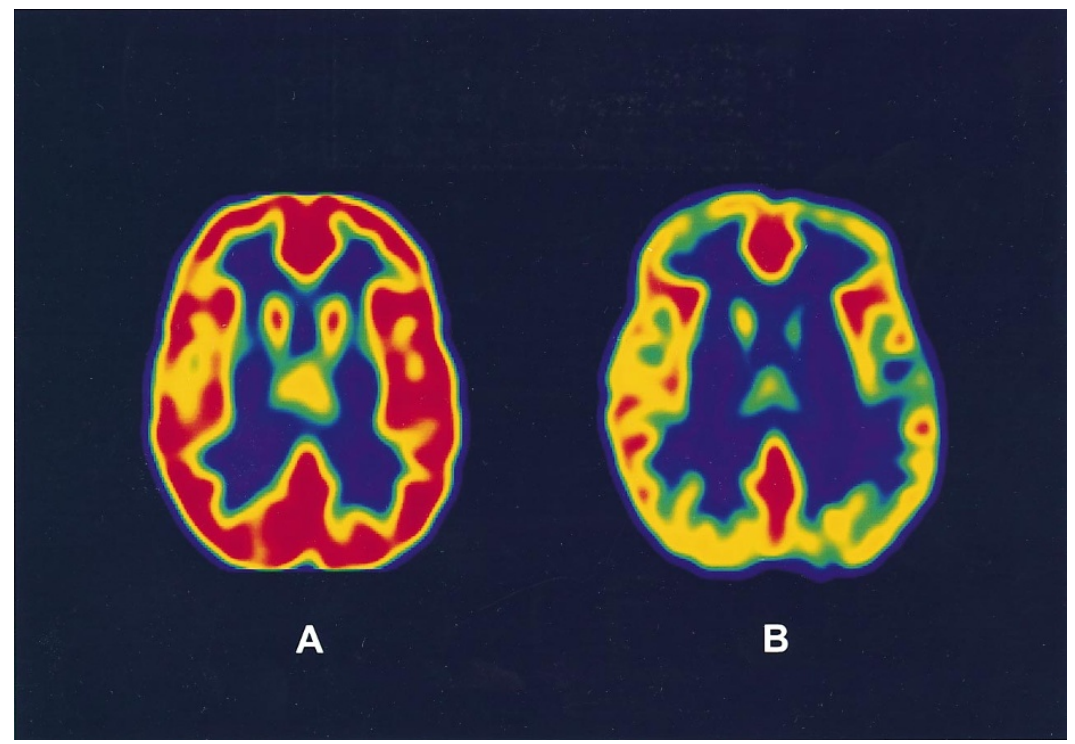

Figure 2. Computer-simulated PET images crated from MR data by arbitrarily assigning GM pixel a value of 120 , WM pixels a value of 40, and CSF pixels a value of 0 to simulate the approximate relationship among these tissues $n$ CBF or CMRGlc, and convolving with a gaussian smoothing kernel [full-width at half-maximum $=8 \mathrm{~mm}$ ]. Simulated PET image in a young healthy subject (age: 32 years) (A) is contrasted with one created using MR data acquired in a normal elderly individual (age: 69 years) (B). Although the values for GM, WM, and CSF were identical in both data sets, the apparent cortical activity is lower in the simulated PET image of the older subject's brain due to dilution of the cortical signal, resulting from partial volume averaging with enlarged CSF spaces. This illustrates the dramatic impact of age-related cerebral atrophy on quantitative PET measures.

group further showed that a selective lesion of serotonergic neurons in the hypothalamus caused large elevations in 5-HT synthesis in many ipsilateral brain structures, particularly the hippocampus (Tsuiki et al. 1995a). PET measurements of 5-HT synthetic rates may improve our understanding of the feedback control mechanisms involved in release and reuptake of 5-HT, and thus may elucidate the mode of action of antidepressants. Application of this technique in humans yielded preliminary evidence suggesting disturbed 5-HT synthesis in depression (Agren and Reibring 1994) and differential regulation of 5-HT synthesis in men and women, which may contribute to the increased vulnerability of women to depression (Nishizawa et al. 1997).

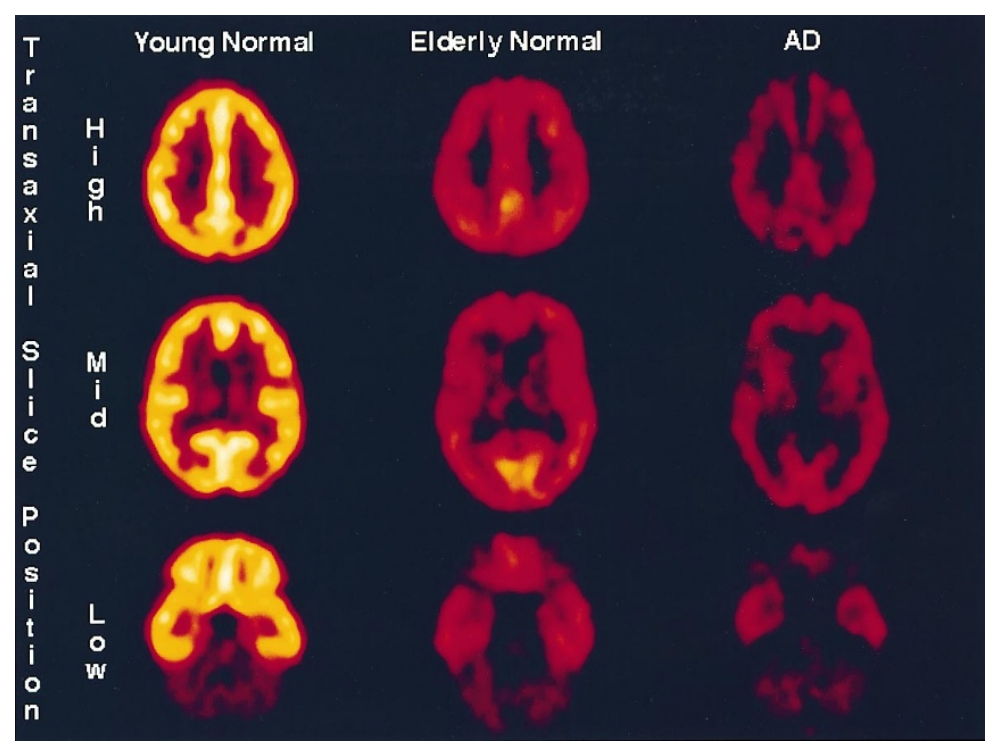

Figure 3. $\quad\left[{ }^{18} \mathrm{~F}\right]$ altanserin PET images summed over the interval 20-90 min post-injection in young normal (age: 20) (left column), elderly normal (age: 66 years) (middle column), and AD (age: 67 years) (right column) subjects. Images are displayed normalized to the cerebellum, an area with few $5-\mathrm{HT}_{2 \mathrm{~A}}$ receptors and therefore reflective of nonspecific activity. Cortical $5-\mathrm{HT}_{2 \mathrm{~A}}$ binding is notably greater in the young relative to the elderly subject. The AD subject exhibits diffuse markedly lower $\left[{ }^{18} \mathrm{~F}\right]$ altanserin binding than both the young and elderly controls. 


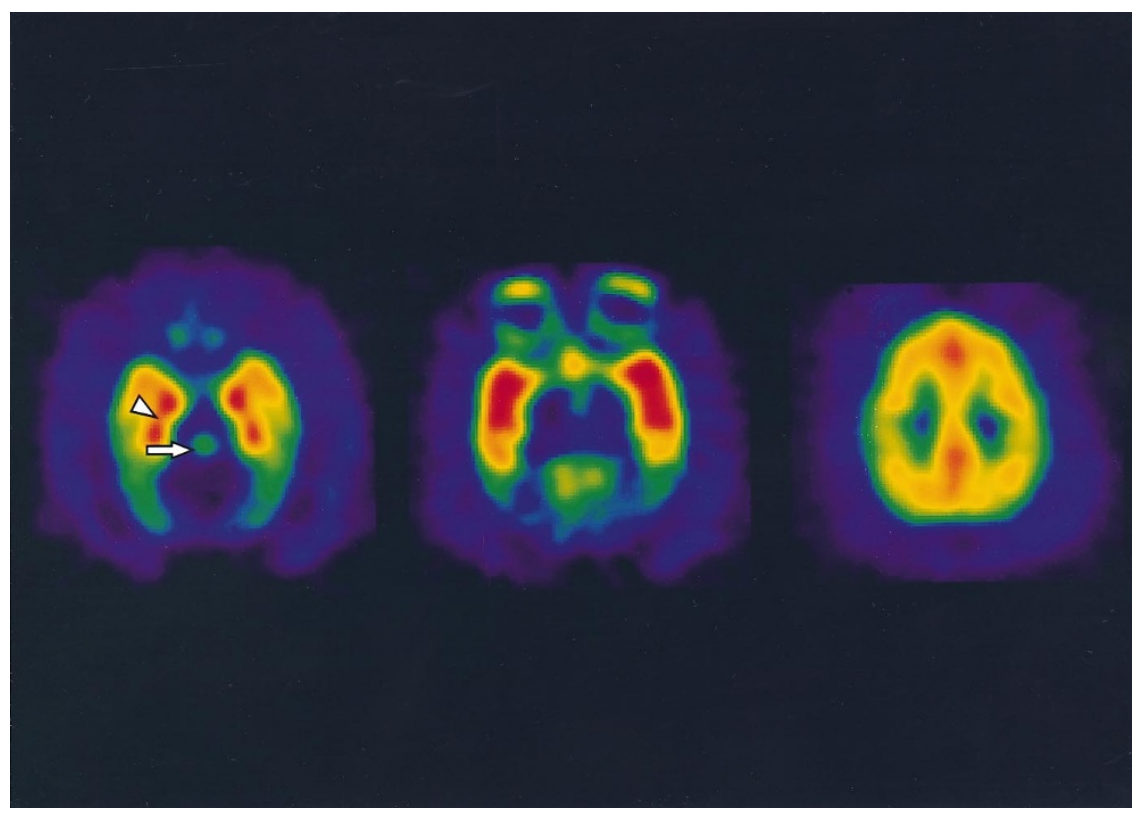

Figure 4. $\left[{ }^{11} \mathrm{C}\right] \mathrm{WAY} 100635$ PET imaging of the $5-\mathrm{HT}_{1 \mathrm{~A}}$ receptor at three levels in a baboon brain (summed over the interval 30-80 min following injection). Binding to areas of known high density of $5-\mathrm{HT}_{1 \mathrm{~A}}$ receptors, such as the hippocampus (arrowhead) and brainstem raphe nuclei (arrow), is demonstrated. Image data were acquired in a 3-dimensional (3D) mode (septa retracted) on an $\mathrm{HR}+$ tomography (Siemens/C.T.I., Knoxville, TN).

\section{CONCLUSIONS}

There is considerable evidence for a central role for 5-HT in depressive illness, however, it remains controversial whether the fundamental defect is in presynaptic serotonergic neurotransmission or postsynaptic function. The influence of age, gender, and factors such as prior antidepressant use, suicidality, violence, and cerebrovascular disease is unclear and a potential source of confusion in interpreting the extensive body of literature on 5-HT in mood disorders. There is increasing evidence for alterations in the function of the 5-HT system in $\mathrm{AD}$, which may be responsible for many of the behavioral aspects of the disease including the frequent coexistence of depression. The literature implicating 5-HT dysfunction in depression and AD is based largely on the results of indirect measures, including animal models, post mortem human studies, and peripheral measurements of 5-HT binding. The evolution of PET technology, with the development of highly selective 5-HT markers, improved spatial resolution, and methods for regional partial volume correction now permits us to in- vestigate specific neurophysiological questions in living human subjects. Using PET to elucidate the neurochemical profile of clinically well-characterized normal elderly, elderly depressed, and AD subjects may lead to the development of more effective treatments for cognitive and mood impairment in the aging population, as well as potentially provide predictors of treatment outcome.

\section{FUTURE DIRECTIONS}

Improved understanding of the nature of alterations in the 5-HT system occurring aging, late-life depression, and dementia has important implications for testing hypotheses of neurochemical mechanisms underlaying the aging process and age-related neuropsychiatric disease. PET imaging of neurotransmitter systems affords a unique in vivo approach to the evaluation of neurochemical dysfunction in elderly subjects suffering from mood disorders with or without cognitive impairment. Such an approach holds promise for guiding the identification of subgroups of patients most likely to benefit

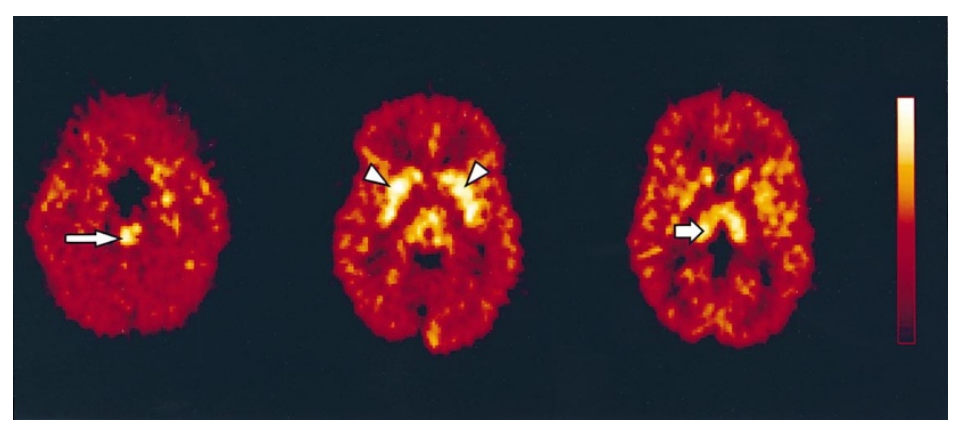

Figure 5. PET images acquired with the selective 5-HT reuptake ligand $\left[{ }^{11} \mathrm{C}\right] \mathrm{McN} 5652 \mathrm{X}$ shown at three levels (left: midbrain, middle: striatum, right: thalamus) in a human brain (summed over the interval 40-120 min following injection) using 3D-PET data acquisition. Tracer localization follows the known distribution of 5-HT reuptake sites, with high binding observed in the region of the brainstem raphe (long arrow), striatum (arrowheads), and thalamus (short arrow). (Images displayed using compressed color scale as per color bar on right.) 
from antidepressant therapy, or alternatively, those individuals with tendencies for recurrent depressive episodes or who are at greatest risk for suicide and thus those who may require close surveillance. This information may provide a basis for both treatment selection and future treatment development. The relationship between late-life depression and $\mathrm{AD}$, which may be best evaluated early in the course of cognitive decline, is particularly difficult to address with post mortem studies and especially suited to investigation with PET imaging techniques. Potential future applications of PET include:

- Characterization in vivo alterations in 5-HT synthesis, specific 5-HT receptor subtypes, and the 5-HT transporter across the life span. PET studies of normal aging would provide a basis for interpretation of changes in 5-HT systems occurring in neuropsychiatric disorders of aging and may elucidate the mechanism underlying an age-related increase in susceptibility to affective and neurodegenerative disorders. Combining this information with markers to identify individuals at high risk for developing these disorders may facilitate the development of neuroprotective strategies.

- Investigation of the balance of pre- and postsynaptic 5-HT influences over the course of the depressive illness. A key strength of PET is the ability to perform longitudinal studies in a single individual. Imaging prior to and following treatment of late-life depression would determine whether changes in receptor binding characteristics with remission can predict short-term therapeutic success. This approach would also provide unique information regarding the neurobiological substrate of "state" versus "trait" aspects of symptomatology in depression. Further, characterizing the dynamic relationship between changes in 5-HT markers and the clinical efficacy of antidepressants may help identify neurochemical indicators of treatment resistance and have implications for the longterm likelihood of relapse. This information may also serve to guide the development of more effective treatments for late-life depression.

- In vivo quantitation of the progression of 5-HT neuron loss (using presynaptic markers for the 5-HT reuptake site) and postsynaptic cortical cell losses in $A D$. This would potentially shed light on whether the serotonergic defect is in the serotonergic raphe neurons or the result of primary cortical neuronal degeneration. This is a controversial issue that may be particularly relevant to the design of successful approaches to the treatment of AD. Given the availability of clinical and genetic markers to identify patients potentially at risk for $\mathrm{AD}$, it is not possible to characterize these changes in the earliest stages of the disease.

- Investigation of the imbalance between 5-HT and other neurotransmitter systems in $A D$. There is considerable evidence for a modulatory interaction between the serotonergic and cholinergic systems, which is implicated in cognitive processes and may be altered in aging and AD. PET may be applied to explore the nature of the interaction among neurotransmitter systems through challenge paradigms. Alternatively, progress in development of selective cholinergic PET ligands may soon permit direct imaging of both serotonergic and cholinergic markers in AD patients. Serial PET imaging studies could be applied to assess the relative changes in the two systems throughout the course of the disease.

- Evaluation of the relationship between late-life depression and $A D$. The well-recognized, but poorly characterized, link between dementia and late-life depression may be investigated with PET, first by clarifying the neurochemical profiles of normal aging, uncomplicated depression, and AD unaccompanied by depression. Thereafter, this information may be applied to study the overlap of depression and AD. Coupling metabolic and neuroreceptor PET imaging and longterm clinical follow-up data may prove useful in identifying early markers of dementia in patients presenting with depression in late life.

\section{ACKNOWLEDGMENTS}

This work was supported in part by PHS grants MH52247, AG05133, MH01210, MH00295, MH37869, MH49936, NS22899, and MH49815, and the Radiological Society of North America Research and Education Fund.

\section{REFERENCES}

Agren H, Reibring L (1994): PET studies of presynaptic monoamine metabolism in depressed patients and healthy volunteers. Pharmacopsychiatry 27:2-6

Albert M, Sandor T, Moss M, Jolesz F (1992): Measurement of age-related differences in gray matter, white matter, and cerebrospinal fluid. Radiology 185(P):200

Alder J, Chen C-H, Francis P, Hope T, Heath P, Bowen D (1995): Pre and postsynaptic serotonergic markers in a community acquired study of Alzheimer's disease. Soc Neurosci Abstr 21(Part 3):1977

Alexopoulos GS, Abrams RC (1991): Depression in Alzheimer's disease. Psychiatr Clin NA 14:327-340

Alexopoulos G, Young R, Shindledecker R (1992): Brain computed tomography findings in geriatric depression and primary degenerative dementia. Biol Psychiatry 31:591-599

Alexopoulos G, Meyers B, Young R, Mattis S, Kakuma T (1993): The course of geriatric depression with "reversible dementia": A controlled study. Am J Psychiatry 150:1693-1699

Alexopoulos G, Meyers B, Young R, Kakuma T, Feder M, 
Einhorn A, Rosendahl E (1996): Recovery in geriatric depression. Arch Gen Psychiatry 53:305-312

Altman HJ, Nordy D, Ogren S (1984): Role of serotonin in memory: Facilitation by alaproclate and zimeldine. Psychopharmacology 84:496-502

Altman HJ, Normile HJ, Galloway MP, Ramirez A, Azmitia EC (1990): Enhanced spatial discrimination learning in rats following 5, 7-DHT-induced serotonergic deafferentation of the hippocampus. Brain Res 518:61-66

Andersson A, Adolfsson R, Eriksson K, Marcusson J (1991): Platelet $\left[{ }^{3} \mathrm{H}\right]$ paroxetine binding to 5 -HT uptake sites in Alzheimer's disease. Neurobiol Aging 12:531-534

Andersson A, Sundman I, Marcusson J (1992): Age stability of human brain 5 -HT terminals studied with $\left.{ }^{3} \mathrm{H}\right]$ paroxetine binding. Gerontology 38:127-132

Arai H, Ichimiya Y, Kosaka K, Moroji T, lizuka R (1992): Neurotransmitter changes in early- and late-onset Alzheimer-type dementia. Prog Neuropsychopharmacol Biol Psychiatry 16:883-890

Arango V, Ernsberger P, Marzuk P, Chen J-S, Tierney H, Stanley M, Reis D, Mann J (1990): Autoradiographic demonstration of increased serotonin $5-\mathrm{HT}_{2}$ and $\beta$-adrenergic receptor binding sites in the brain of suicide victims. Arch Gen Psychiatry 47:1038-1047

Arango V, Underwood M, Mann J (1992): Alterations in monoamine receptors in the brian of suicide victims. J Clin Psychopharmacol 12(Suppl.): 8S-12S

Arango V, Underwood M, Gubbi A, Mann J (1995): Localized alterations in pre- and postsynaptic serotonin binding sites in the ventrolateral prefrontal cortex of suicide victims. Brain Res 688:121-133

Arora R, Meltzer H (1989a): ${ }^{3} \mathrm{H}$-imipramine binding in the frontal cortex of suicides. Psychiatr Res 30:125-135

Arora R, Meltzer H (1989b): Serotonergic measures in the brains of suicide victims: $5-\mathrm{HT}_{2}$ binding sites in the frontal cortex of suicide victims and control subjects. Am J Psychiatry 146:730-736

Arora R, Emery O, Meltzer H (1991): Serotonin uptake in the blood platelets of Alzheimer's disease patients. Neurology 41:1307-1309

Arranz B, Eriksson A, Mellerup E, Plenge P, Marcusson J (1993): Effect of aging in human cortical pre- and postsynaptic serotonin binding sites. Brain Res 620:163166

Ashworth S, Hume S, Lammertsma A, Opacka-Juffry J, Shah F, Pike V (1996): Development of central 5- $\mathrm{HT}_{2 \mathrm{~A}}$ receptor radioligands for PET: Comparison of $\left[{ }^{3} \mathrm{H}\right] \mathrm{RP} 62203$ and $\left[{ }^{3} \mathrm{H}\right] \mathrm{SR} 46349 \mathrm{~B}$ kinetics in rat brain. Nucl Med Biol 23:245-250

Azmitia EC, Whitaker-Azmitia PM (1991): Awakening the sleeping giant: Anatomy and plasticity of the brain serotonergic system. J Clin Psychiatry 52:4-16

Baldwin RC, Tomenson B (1995): Depression in later life. A comparison of symptoms and risk factors in early and late onset cases. Br J Psychiatry 167:649-652

Barnes J, Barnes N, Costall B, Naylor R, Tyers M (1989): 5-HT receptors mediate inhibition of acetylcholine release in cortical tissue. Nature 338:762-763

Baxter L, Schwartz J, Phelps M, Mazziotta J, Guze B, Selin C,
Gerner R, Sumida R (1989): Reduction of prefrontal cortex glucose metabolism common to three types of depression. Arch Gen Psychiatry 46:243-250

Beats B, Levy R, Forstl H (1991): Ventricular enlargement and caudate hyperdensity in elderly depressives. Biol Psychiatry 30:452-458

Bench C, Friston K, Brown R, Scott L, Frackowiak R, Dolan R (1992): The anatomy of melancholia-Focal abnormalities of cerebral blood flow in major depression. Psychol Med 22:607-615

Bergman I, Brane G, Gottfries CG, Jostell K-G, Karlsson I, Svennerholm L (1983): Alaproclate: A pharmacokinetic and biochemical study in patients with dementia of the Alzheimer type. Psychopharmacology 80:279-283

Biegon A, Greuner N (1992): Age-related changes in serotonin $5 \mathrm{HT}_{2}$ receptors on human blood platelets. Psychopharmacology 180:210-212

Biver F, Goldman S, Luxen A, Monclus M, Forestini M, Mendlewicz J, Lotstra F (1994): Multicompartmental study of fluorine- 18 altanserin binding to brain $5 \mathrm{HT}_{2}$ receptors in humans using positron emission tomography. Eur J Nucl Med 21:937-946

Biver F, Lotstra F, Monclus M, Wikler D, Damhaut P, Mendlewicz J, Goldman S (1996): Sex difference in $5 \mathrm{HT}_{2}$ receptors in the living human brain. Neurosci Lett 204: $25-28$

Biver F, Lotstra F, Monclus M, Dethy S, Damhaut P, Wikler D, Luxen A, Goldman S (1997): In vivo binding of $\left[{ }^{18} \mathrm{~F}\right]$ altanserin to rat brain $5 \mathrm{HT}_{2}$ receptors: A film and electronic autoradiographic study. Nucl Med Biol 24: $357-360$

Blazer D, Hughes D, George L (1987): The epidemiology of depression in an elderly community population. Gerontologist 27:281-287

Blier P, de Montigny C, Chaput Y (1990): A role for the serotonin system in the mechanism of action of antidepressant treatments: preclinical evidence. J Clin Psychiatry 51:14-20

Blin J, Baron JC, Dubois B, Crouzel C, Fiorelli M, Attar-Levy D, Pillon B, Fournier D, Vidailhet M, Agid Y (1993): Los of brain $5 \mathrm{HT}_{2}$ receptors in Alzheimer's disease. Brain 116:497-510

Bonne O, Krausz Y, Shapira B, Bocher M, Karger H. Gorfine M, Chisin R, Lerer B (1996): Increased cerebral blood flow in depressed patients responding to electroconvulsive therapy. J Nucl Med 37:1075-1080

Bonte FJ, Ross ED, Chehabi HH, Devous MD (1986): SPECT study of regional cerebral blood flow in Alzheimer disease. J Comput Assist Tomogr 10:579-583

Bonte FJ, Hom J, Tintner R, Weiner MF (1990): Single photon tomography in Alzheimer disease and the dementias. Semin Nucl Med 20:342-352

Borson S, Barnes R, Kukull W. Okimoto J, Veith R, Inui T, Carter W, Raskind M (1986): Symptomatic depression in elderly medical outpatients. I. Prevalence, demography, and health service utilization. J Am Geriatr Soc 34:341-347

Bowen DM, Allen SJ, Benton JS, Goodhardt MJ, Haan EA, Palmer AM, Sims NR, Smith CCT, Spillane JA, Esiri MM, Neary D, Snowdon JS, Wilcock GK, Davison AN (1983): Biochemical assessment of serotonergic and cho- 
linergic dysfunction and cerebral atrophy in Alzheimer's disease. J Neurochem 41:266-272

Bowen DM, Najlerahim A, Procter A, Francis P, Murphy E (1989): Circumscribed changes of the cerebral cortex in neuropsychiatric disorders of late life. Proc Natl Acad Sci USA 86:9504-9508

Briley M, Langer S, Raisman R, Sechter D, Zarifian E (1980): Tritiated imipramine binding sites are decreased in platelets of untreated depressed patients. Science 209:303-305

Burke WJ, Chung HD, Huang JS, Huang SS, Haring JH, Strong R, Marshall GL, Joh TH (1988): Evidence for retrograde degeneration of epinephrine neurons in Alzheimer's disease. Ann Neurol 24:532-536

Burns A, Tyrrell P (1992): Association of age with regional cerebral oxygen utilization: A positron emission tomography study. Age Aging 21:316-320

Carli M, Tranchina S, Samanin R (1992): 8-Hydroxy-2-(din-propylamino)tetralin, $5-\mathrm{HT}_{1 \mathrm{~A}}$ receptor agonist, impairs performance in a passive avoidance task. Eur J Pharmacol 211:227-234

Casey D (1994): Depression in the elderly. South Med J 87(5):559-563

Chan-Palay V (1976): Serotonin axons in the supra- and subependymal plexuses and in the leptomeninges: Their roles in local alterations of cerebrospinal fluid and vasomotor activity. Brian Res 102:103-130

Chawluk J, Alavi A, Hurtig H, Dann R, Rosen M, Kushner MJ, Silver FL, Reivich M (1985): Altered patterns of regional cerebral glucose metabolism in aging and dementia. J Cereb Blood Flow Metab 5(Suppl. 1):S121-S122

Cheetham S, Crompton M, Katona C, Horton R (1988): Brain $5-\mathrm{HT}_{2}$ receptor binding sites in depressed suicide victims. Brain Res 443:272-280

Chen C-H, Hope R, Alder J, Eastwood S, Gedling K, McDonald B, Francis P, Esiri M, Bowen D (1995): Loss of paroxetine binding in the neocortex is associated with depression in Alzheimer's disease. In Iqbal K, Mortimer J, Winblad B, Wisniewski H (eds), Research Advances in Alzheimer's Disease and Related Disorders. New York, John Wiley \& Sons Ltd, pp 467-473

Chen C-H, Alder J, Bowen D, Esiri M, McDonald B, Hope T, Jobst K, Francis P (1996): Presynaptic serotonergic markers in community-acquired cases of Alzheimer's disease: Correlations with depression and neuroleptic medication. J Neurochem 66:1592-1598

Cheng AVT, Ferrier IN, Morris CM, Jabeen S, Sahgal A, McKeith IG, Edwardson JA, Perry RH, Perry EK (1991): Cortical serotonin- $\mathrm{S}_{2}$ receptor binding in Lewy body dementia, Alzheimer's and Parkinson's diseases. J Neurol Sci 106:50-55

Coffey CE, Wilkinson WE, Parashos IA, Soady SAR, Sullivan RJ, Patterson LJ, Figiel GS, Webb MC, Spritzer CE, Djang WT (1992): Quantitative cerebral anatomy of the aging human brain: A cross-sectional study using magnetic resonance imaging. Neurology 42:527-536

Condon B, Wyper D, Grant R, Patterson J, Hadley D, Teasdale G, Rowan J (1986): Use of magnetic resonance imaging to measure intracranial cerebrospinal fluid volume. Lancet 1:1355-1357

Costall B, Barnes JM, Hamon M, Muller WE, Briley M (1990):
Biochemical models for cognition enhancers. Pharmacopsychiatry 23(Suppl. 2):85-88

Cowen P (1993): Serotonin receptor subtypes in depression: Evidence from studies in neuroendocrine regulation. Clin Neuropharmacol 16(Suppl. 3):6-18

Craik F, Jennings J (1992): Human Memory. In Craik F, Salthouse T (eds), The Handbook of Aging and Cognition. New York, Lawrence Elrbaum Publishers, pp 51-111

Cross AJ (1990): Serotonin in Alzheimer-type dementia and other dementing illness. Ann NY Acad Sci 600:405-417

Cross A, Crow T, Ferrier I, Johnson J, Bloom S, Corsellis J (1984): Serotonin receptor changes in dementia of Alzheimer type. J Neurochem 43:1574-1581

Cross P, Gurland B (1986): The Epidemiology of Dementing Disorders (Contract report prepared for the Office of Technology Assessment, U.S. Congress). Washington, DC, U.S. Government Printing Office

Crouzel C, Guillaume M, Barre L, Lemaire C, Pike V (1992): Ligands and tracers for PET studies of the 5-HT system-current status [review]. Int J Radiat Appl Instrum Part B, Nucl Med Biol 19:857-870

Crow T, Cross A, Cooper S, Deakin J, Ferrier I, Johnson J. Joseph M, Owen FMP, Lofthouse R, Corsellis J, Chambers D, Blessed G, Perry E, Perry R, Tomlinson B (1984): Neurotransmitter receptors and monoamine metabolites in the brains of patients with Alzheimer-type dementia and depression, and suicides. Neuropharmacology 23:1561-1569

Curcio C, Kemper T (1984): Nucleus raphe dorsalis in dementia of the Alzheimer type: Neurofibrillary changes and neuronal packing density. J Neuropathol Exp Neurol 43:359-368

Cutler NR, Haxby JV, Duara R, Grady CL, Kay AD, Kessler RM, Sundaram M, Rapoport SI (1985): Clinical history, brain metabolism, and neuropsychological function in Alzheimer disease. Ann Neurol 18:298-309

D'Amato R, Zwieg R, Whitehouse P, Wenk G, Singer H, Mayeaux R, Price D, Snyder S (1987): Aminergic systems in Alzheimer's disease and Parkinson's disease. Ann Neurol 22:229-239

Davies P, Maloney AJ (1976): Selective loss of central cholinergic neurons in Alzheimer's disease [letter]. Lancet 2:1403

Dawson T, Wamseley J (1983): Autoradiographic localization of $\left[{ }^{3} \mathrm{H}\right]$ imipramine binding sites: Association with serotonergic neurons. Brain Res Bull 11:325-334

DeKosky S, Palmer A (1994): Neurochemistry of aging. In Albert M, Knoefel J (eds), Clinical Neurology of Aging. New York, Oxford Press, pp 79-101

DeKosky S, Scheff S, Markesberry W (1985): Laminar organization of cholinergic circuits in human frontal cortex in Alzheimer's disease and aging. Neurology 35:1425-1431

DeKosky S, Shih W-J, Schmitt F, Coupal J, Kirkpatrick C (1990): Assessing utility of single photon emission computerized tomography (SPECT) scan in Alzheimer's disease: Correlation with cognitive severity. Alzheimer's Disease Related Disorders 4:14-23

de Leon M, Ferris S, George A, Christman D, Fowler J, Gentes C, Reisberg B, Gee B, Emmerich M, Yonekura Y, Brodie J, Kricheff I, Wolf A (1983): Positron emission 
tomographic studies of aging and Alzheimer disease. Am J Neuroradiol 4:568-571

de Montigny C (1984): Electroconvulsive shock treatment enhance responsiveness of forebrain neurons to serotonin. J Pharmacol Exp Ther 228:230-234

Delgado P, Charney D, Price L, Aghajanian G, Landis H, Heninger G (1990): Serotonin function and the mechanism of antidepressant action. Arch Gen Psychiatry 47:411-418

Denys A, Maunoury C, Cuenod C, Boller F, Jehenson P (1992): Amygdala and hippocampal formation MR measurements: diagnostic value in early stage of Alzheimer disease. Radiology 185(P):200

Descarries L, Beaudet A, Watkins K (1975): Serotonin nerve terminals in adult rat neocortex. Brain Res 100:563-588

Devanand D, Sano M, Tang M-X, Taylor S, Gurland B, Wilder D, Stern Y, Mayneux R (1996): Depressed mood and the incidence of Alzheimer's disease in the elderly living in the community. Arch Gen Psychiatry 53:175182

Dewar D, Graham D, McCulloch J (1990): 5- $\mathrm{HT}_{2}$ receptors in dementia of Alzheimer type: A quantitative autoradiographic study of frontal cortex and hippocampus. J Neural Transm 2:129-137

Dewey S, Tan P, Smith G, King P, Pappas N, MacGregor R, Ding Y-S, Shea C, Alexoff D, Martin T, Gatley S, Fowler J, Wolf A (1994): PET and in vivo microdialysis studies of SR 46349B, a new and selective 5- $\mathrm{HT}_{2}$ antagonist. Soc Neurosci Abstr 20:1552

D'haenen H, Bossuyt A, Mertens J, Bossuyt-Piron C, Gijsemans M, Kaufman L (1992): SPECT Imaging of serotonin $_{2}$ receptors in depression. Psychiatr Res: Neuroimaging 45:227-237

Diksic M, Nagahiro S, Chaly T, Sourkes T, Yamamoto Y, Feindel W (1991): Serotonin synthesis rate measured in living dog brain by positron emission tomography. J Neurochem 56:153-160

Diksic M, Nagahiro S, Grdisa M (1995): The regional rate of serotonin synthesis estimated by the $\delta$-methyl-tryptophan method in rat brain from a single time point. J Cereb Blood Flow Metab 15:806-813

Dillon K, Gross-Isseroff R, Israeli M, Biegon A (1991): Autoradiographic analysis of serotonin $5-\mathrm{HT}_{1 \mathrm{~A}}$ receptor binding in the human brain postmortem: Effects of age and alcohol. Brain Res 554:56-64

Drevets WC, Videen TO, Price JL, Preskorn SH, Carmichael ST, Raichle ME (1992): A functional anatomical study of unipolar depression. J Neurosci 12:3628-3641

Drevets W, Price J, Simpson J, Todd R, Reich T, Raichle M (1996): State- and trait-like neuroimaging abnormalities in depression: effects of antidepressant treatment. Soc Neurosci Abstr 22:264

Duara R, Grady C, Haxby J, Ingvar D, Sokoloff L, Margolin R, Manning R, Cutler NR, Rappaport SI (1984): Human brain glucose utilization and cognitive function in relation to age. Ann Neurol 16:702-713

Duara R, Grady C, Haxby J, Sundaram M, Cutler NR, Heston L, Moore A, Schlageter N, Larson S, Rappaport SI (1986): Positron emission tomography in Alzheimer's disease. Neurology 36:879-887
Edwards E, Harkins K, Wright G, Henn F (1991): 5- $\mathrm{HT}_{1 \mathrm{~b}}$ receptors in an animal model of depression. Neuropharmacology 30:101-105

Ellis P, Beeston R, McIntosh C, Salmond C, Cooke R (1992): Platelet ${ }^{3} \mathrm{H}$-imipramine binding during recovery from depression. Acta Psychiatr Scand 86:108-112

Engleman E, Murphy J, Zhou F, Hingtgen J (1992): Response suppression induced with selective 5-HT agonists can be differentially blocked with LY53857 in an animal model of depression. Neurochem Res 176:483-488

Erkinjuntti T, Lee DH, Gao F, Steenhuis R, Eliasziw M, Fry R, Merskey H, Hachinski VC (1993): Temporal lobe atrophy on magnetic resonance imaging in the diagnosis of early Alzheimer's disease. Arch Neurol 50:305-310

Ernst RL, Hay JW (1994): The US economic and social costs of Alzheimer's disease revisited. Am J Public Health 84:1261-1264

Evans D, Funkenstein H, Albert M, Scherr P, Cook N, Chown M, Herbert L, Hennekens C, Taylor J (1989): Prevalence of Alzheimer's disease in a community population of older persons: Higher than previously reported. JAMA 262:2551-2556

Figiel G, Krishnan K, Doraiswamy P, Rao V, Nemeroff C, Boyko O (1991): Subcortical hyperintensities on brain magnetic resonance imaging: A comparison between late age onset and early onset elderly depressed subjects. Neurobiol Aging 12:245-247

Fisher P, Simanyi M, Danielczyk W (1990): Depression in dementia of the Alzheimer type and in multi-infarct dementia. Am J Psychiatry 147:1484-1487

Fitz AG, Teri L (1994): Depression, cognition, and functional ability in patients with Alzheimer's disease. J Am Geriatr Soc 42:186-191

Fletcher A, Pike VW, Cliffe IA (1995): Visualization and characterization of 5-HT receptors and transporters in vivo and in man. Semin Neurosci 7:421-431

Foster NL, Chase TN, Mansi L, Brooks R, Fedio P, Patronas NJ, Di Chiro G (1984): Cortical abnormalities in Alzheimer's disease. Ann Neurol 16:649-654

Francis PT, Pangalos MN, Stephens PH, Bartlett JR, Bridges PK, Malizia AL, Neary D, Proctor AW, Thomas DJ, Bowen DM (1993): Antemortem measurements of neurotransmission: Possible implications for pharmacotherapy of Alzheimer's disease and depression. J Neurol Neurosurg Psychiatry 56:80-84

Frankfurt M, McKittrick C, Mendelson S, McEwen B (1994): Effect of 5, 7-dihydroxy-tryptamine, ovariectomy and gonadal steroids on serotonin receptor binding in rat brain. Neuroendocrinology 59:245-250

Friedland RP, Budinger TF, Ganz E, Yano Y, Mathis CA, Koss B, Ober BA, Huesman RH, Derenzo SE (1983): Regional cerebral metabolic alterations in dementia of the Alzheimer type: Positron emission tomography with 18F-fluorodeoxyglucose. J Comput Assist Tomogr 7:590-598

Frlich L, Eilles C, Ihl R, Maurer K, Lanczik M (1989): Stagedependent reductions of regional cerebral blood flow measured by HMPAO-SPECT in dementia of Alzheimer type. Psychiatry Res 29:347-350

Frost J (1990: Imaging the serotonergic system by positron emission tomography. Ann NY Acad Sci 600:272-280 
Fuxe K, Calza L, Benfenati F, Zini I, Agnatti L (1983): Quantitative autoradiographic localization of $[3 \mathrm{H}]$ imipramine binding sites in the brain of the rat. Relationship to ascending 5-hydroxytryptamine neuron systems. Proc Natl Acad Sci USA 80:3836-3840

German DC, White CLD, Sparkman DR (1987): Alzheimer's disease: Neurofibrillary tangles in nuclei that project to the cerebral cortex. Neuroscience 21:305-312

Gilewski MJ, Farberow NL, Gallagher DE, Thompson LW (1991): Interaction of depression and bereavement on mental health in the elderly. Psychol Aging 6:67-75

Golden RN, Gilmore JH, Corrigan MHN, Ekstrom RD, Knight BT, Garbutt JC (1991): Serotonin, suicide, and aggression: clinical studies . J Clin Psychiatry 52:61-69

Gonzales G, Carillo C (1993): Blood serotonin levels in postmenopausal women: Effects of age and serum oestradiol levels. Maturitas 17:23-29

Gottfries C (1990): Neurochemical aspects on aging and disease with cognitive impairment. J Neurosci Res 27:541547

Gross-Isseroff R, Salama D, Isreli M, Biegon A (1990): Autoradiographic analysis of $\left[{ }^{3} \mathrm{H}\right]$ ketansterin binding in the human brain postmortem: effect of suicide. Brain Res 507:208-215

Hajdu MA, McElmurry RT, Heistad DD, Baumbach GL (1993): Effects of aging on cerebral vascular responses to serotonin in rats. Am J Physiol 264:H2136-2140

Halliday GM, McCann HL, Pamphlett R, Brooks WS, Creasey H, McCusker E, Cotton RGH, Broe GA, Harper CG (1992): Brain stem serotonin-synthesizing neurons in Alzheimer's disease: A clinicopathological correlation. Acta Neuropathol 84:638-650

Hayakawa H, Okamoto Y, Shimizu M, Nishida A, Motohashi N, Yamawaki S (1995): Single or repeated treatment with electroconvulsive shock increases number of serotonin uptake binding sites in the frontal cortex. Biol Psychiatry 31:1-5

Holman BL, Nagel JS, Johnson KA, Hill TC (1991): Imaging dementia with SPECT. Ann NY Acad Sci 620:165-174

Hoyer D, Martin G (1997): 5-HT receptor classification and nomenclature: Towards a harmonization with the human genome. Neuropharmacology 36:419-428

Hrdina P, Foy B, Hepner A, Summers R (1990): Antidepressant binding sites in brain: Autoradiographic comparison of $\left[{ }^{3} \mathrm{H}\right]$ paroxetine and $\left[{ }^{3} \mathrm{H}\right]$ imipramine localization and relationship to serotonin transporter. J Pharmacol Exp Ther 252:410-418

Hrdina P, Demeter E, Vu T, Sotonyi P, Palkovits M (1993): 5-HT uptake sites and $5-\mathrm{HT}_{2}$ receptors in brain of antidepressant-free suicide victims/depressives: Increase in 5- $\mathrm{HT}_{2}$ sites in cortex and amygdala. Brain Res 614:37-44

Hume SP, Ashworth S, Opacka-Juffry J, Ahier RG, Lammertsma AA, Pike VW, Cliffe IA, Fletcher A, White AC (1994): Evaluation of [O-methyl-3H]WAY-100635 as an in vivo radioligand for 5-HT1A receptors in rat brain. Eur J Pharmacol 271:515-523

Husain M, Knight D, Doraiswamy P, Krishnan K, Nemeroff C (1991): Platelet [3H]-imipramine binding and leukoencephalopathy in geriatric depression. Biol Psychiatry 29:665-670
Inestrosa N, Alarcon R, Arrigada J, Donoso A, Alverez J (1993): Platelet of Alzheimer patients: Increased counts and subnormal uptake of accumulation of $\left[{ }^{14} \mathrm{C}\right] 5$ hydroxytryptamine. Neurosci Lett 163:8-10

Iyo M, Yamasaki T (1993): The detection of age-related decrease of dopamine $\mathrm{D}_{1}, \mathrm{D}_{2}$ and serotonin 5- $\mathrm{HT}_{2}$ receptors in living human brain. Prog Neuro-Psychopharmacol Biol Psychiatry 17:415-421

Jack CR, Petersen RC, O’Brien PC, Tangalos EG (1992): MRbased hippocampal volumetry in the diagnosis of Alzheimer disease. Neurology 42:183-188

Jacobs B, Azmitia E (1992): Structure and function of the brain serotonin system. Physiol Rev 72:165-229

Jaffe E, De Frias V, Ibarra C (1993): Changes in basal and stimulated release of endogenous serotonin from different nuclei of rats subjected to two models of depression. Neurosci Lett 162:157-160

Jagust WJ, Budinger TF, Reed BR (1987): The diagnosis of dementia with single photon emission computed tomography. Arch Neurol 44:258-262

Jagust WJ, Reed BR, Seab PJ, Budinger TF (1990): Alzheimer disease: Age at onset and single-photon emission computed tomographic patterns of regional cerebral blood flow. Arch Neurol 47:628-633

Jamieson DG, Chawluk JB, Alavi A, Hurtig HI, Rosen M, Bais S, Dann R, Kushner M, Reivich M (1987): The effect of disease severity on local cerebral glucose metabolism in Alzheimer's disease. J Cereb Blood Flow Metab 7:S410

Jansen KLR, Faull RLM, Dragunow M, Synek BL (1990): Alzheimer's disease: Changes in hippocampal N-methylD-aspartate, quisqualate, neurotensen, adenosine, benzodiazepine, serotonin and opioid receptors-An autoradiographic study. Neuroscience 39:613-627

Jernigan TL, Press GA, Hesselink JR (1990): Methods for measuring brain morphologic features on magnetic resonance images. Arch Neurol 47:27-32

Kennedy GJ, Kelman HR, Thomas C (1991): Persistence and remission of depressive symptoms in late life. Am J Psychiatry 148:174-178

Kennett G (1991): Mechanisms of serotonergic affect control. In Schwarcz R, Young S, Brown R (eds), Kynurenine and Serotonin Pathways. New York, Plenum Press, pp 231-243

Komahashi T, Ohmori K, Nakana T, Fujinuma H, Higashimoto T, Nakaya M, Kuroda J, Asahi H, Yoshikawa J, Mastumura S (1994): Epidemiological survey of dementia and depression among the aged living in the community in Japan. Jpn J Psychiatry Neurol 48:517-526

Koren P, Diver-Haber A, Adunsky A, Rabinowitz M, Hershkowitz M (1993): Uptake of serotonin into platelets of senile dementia of the Alzheimer type patients. J Gerontol 48:B93-B96

Kostowski W, Dyr W, Krzascik P, Jarbe T, Archer T (1992): 5-hydroxytryptamine ${ }_{1 \mathrm{~A}}$ receptor agonists in animal models of depression and anxiety. Pharmacol Toxicol 71:24-30

Kovachich G, Aronson C, Brunswick D (1992): Effect of repeated administration of antidepressants on serotonin uptake sites in limbic and neocortical structures of rat brain determined by quantitative autoradiography. Neuropsychopharmacology 7:317-324 
Kral VA, Emery OB (1989): Long-term follow-up of depressive pseudodementia of the aged. Can J PsychiatryRevue Canadienne de Psychiatrie 34:445-446

Kuhl D, Metter E, Riege W, Phelps M (1982): Effects of human aging on patterns of local cerebral glucose utilization determined by the $[18 \mathrm{~F}]$ fluorodeoxyglucose method. J Cereb Blood Flow Metab 2:163-171

Kumar A, Newberg A, Alavi A, Berlin J, Smith R, Reivich M (1993): Regional cerebral glucose metabolism in late-life depression and Alzheimer disease: A preliminary positron emission tomography study. Proc Natl Acad Sci USA 90:7019-7023

Kumar A, Miller D, Samuels S, Burke L, Ewbank D, Gottlieb G (1994): MRI volumetrics in late life depression and Alzheimer's disease. Biol Psychiatry 35:615-747

Lawlor BA, Sunderland T, Mellow AM, Molchan SE, Martinez R, Murphy DL (1991): A pilot placebo-controlled study of chronic m-CPP administration in Alzheimer's disease. Biol Psychiatry 30:140-144

Lawrence K, De Paermentier F, Cheetham S, Crompton M, Katona C, Horton R (1990): Brain 5-HT uptake sites, labelled with $\left[{ }^{3} \mathrm{H}\right]$ paroxetine, in antidepressant-free depressed suicides. Brain Res 526:17-22

Leake A, Fairbairn A, McKeith I, Ferrier I (1991): Studies on the serotonin uptake binding site in major depressive disorder and control post-mortem brain: Neurochemical and clinical correlates. Psychiatry Res 39:155-165

Lemaire C, Cantineau R, Guillaume M, Plenevaux A, Christiaens L (1991): Fluorine-18altanserin: A radioligand for the study of serotonin receptors with PET: Radiolabeling and in vivo biologic behavior in rats. J Nucl Med 32:2266-2272

Leysen J (1990): Gaps and peculiarities in 5- $\mathrm{HT}_{2}$ receptor studies. Neuropsychopharmacology 3:361-369

Little J, Broocks A, Martin A, Hill J, Tune L, Mack C, Cantillon M, Molchan S, Murphy D, Sunderland T (1995): Serotonergic modulation of anticholinergic effects on cognition and behavior in elderly humans. Psychopharmacology 120:280-288

Loessner A, Alavi A, Lewandrowski K-U, Mozley D, Souder E, Gur R (1995): Regional cerebral function determined by FDG-PET in healthy volunteers: Normal patterns and changes with age. J Nucl Med 36:1141-1149

Lundkvist C, Halldin C, Ginovart N, Nyberg S, Swahn C-G, Carr A, Brunner F, Farde L (1996): [ ${ }^{11}$ C]MDL 100907, a radioligand for selective imaging of $5-\mathrm{HT}_{2 \mathrm{~A}}$ receptors with positron emission tomography. Life Sci 58:187-192

Luscombe G P, Martin KF, Hutchins LJ, Gosden J, Heal DJ (1993): Mediation of the antidepressant-like effect of 8 -OH-DPAT in mice by postsynaptic $5-\mathrm{HT}_{1 \mathrm{~A}}$ receptors. Br J Pharmacol 108:669-677

Maes M, Meltzer H (1995): The serotonin hypothesis of major depression. In Bloom F, Kupfer D (eds), Psychopharmacology: The Fourth Generation of Progress. New York, Raven Press, Ltd, pp 933-944

Mann DMA, Yates PO, Marcyniuk B (1984): Alzheimer's presenile dementia, senile dementia of Alzheimer type and Down's syndrome in middle age form an agerelated continuum of pathological changes. Neuropathol Appl Neurobiol 10:185-207

Mann J, Malone K, Diehl D, Perel J, Cooper T, Mintun M
(1996): Demonstration in vivo of reduced serotonin responsivity in the brain of untreated depressed patients. Am J Psychiatry 153:174-182

Marcusson J, Morgan D, Winblad B, Finch C (1984a): Serotonin-2 binding sites in human frontal cortex and hippocampus. Selective loss of S-2A sites with age. Brain Res 311:51-56

Marcusson J, Oreland L, Winblad B (1984b): Effect of age on human brain serotonin (S-1) binding sites. J Neurochem 43:1699-1705

Marcusson J, Alafuzoff I, Backstrom I, Ericson E, Gottfries C, Winblad B (1987): 5-Hydroxytryptamine-sensitive [3H]imipramine binding of protein nature in the human brain. II. Effect of normal aging and dementia disorders. Brain Res 425:137-145

Marcyniuk B, Mann DM, Yates PO (1986): The topography of cell loss from locus coeruleus in Alzheimer's disease. J Neurol Sci 76:335-345

Martin A, Friston K, Colebatch J, Frackowiak R (1991): Decreases in regional cerebral blood flow with normal aging. J Cereb Blood Flow Metab 11:684-689

Mathis CA, Simpson NR, Mahmood K, Kinahan PE, Mintun MA (1994): [ $\left.{ }^{11} \mathrm{C}\right]$ Way 100635: A radioligand for imaging $5-\mathrm{HT}_{1 \mathrm{~A}}$ receptors with positron emission tomography. Life Sci 55: PL403-407

Mathis CA, Huang Y, Simpson NR, Mahmood K, Gerdes JM, Price JC (1995): [ $\left.{ }^{11} \mathrm{C}\right] \mathrm{MDL} 100,907$ : A potent and selective antagonist of $5-\mathrm{HT}_{2 \mathrm{~A}}$ receptors labelled with $11 \mathrm{C}$ at two different positions. J Labelled Compd Radiopharm 27:316-318

Mathis CA, Mahmood K, Huang Y, Simpson NR, Gerdes JM, Price JC (1996): Synthesis and preliminary in vivo evaluation of $\left[{ }^{11} \mathrm{C}\right] \mathrm{MDL}$ 100907: A potent and selective radioligand for the $5-\mathrm{HT}_{2 \mathrm{~A}}$ receptor system. Med Chem Res $6: 1-10$

Matsubara S, Arora R, Meltzer H (1991): Serotonergic measures in suicide brain: $5 \mathrm{HT}_{1 \mathrm{~A}}$ binding sites in frontal cortex of suicide victims. J Neural Transm 85:181-194

Mayberg H (1994): Frontal lobe dysfunction in secondary depression. J Neuropsychiatry 428-442

Mayberg H, Brannan S, Liotti M, Mahurin R, Brickman J, Silva J, Tekell C, Jerebek P, Martin C, Fox P (1996): The role of the cingulate in mood homeostasis. Soc Neurosci Abstr 22:267

McBean DE, Sharkey J, Ritchie IM, Kelly PA (1990): Evidence for a possible role for serotonergic systems in the control of cerebral blood flow. Brain Res 537:307-310

McBean DE, Sharkey J, Ritchie IM, Kelly PA (1991): Cerebrovascular and functional consequences of $5-\mathrm{HT}_{1 \mathrm{~A}}$ receptor activation. Brain Res 555:159-163

McBride P, Brown R, DeMeo M, Keilp J, Mieczkowski T, Mann J (1994): The relationship of platelet 5- $\mathrm{HT}_{2}$ receptor indices to major depressive disorder, personality traits, and suicidal behavior. Biol Psychiatry 35:295-308

McGuire M, Rabins P (1994): Mood disorders. In Coffey C, Cummings J (eds), The American Psychiatric Press Textbook of Geriatric Neuropsychiatry. Washington, DC/ London, American Psychiatric Press, Inc, pp 244-260

McLoughlin D, Lucey J, Dinan T (1994): Central serotonergic hyperresponsivity in late-onset Alzheimer's disease. Am J Psychiatry 151:1701-1703 
Meltzer CC, Leal JP, Mayberg HS, Wagner HJ, Frost JJ (1990): Correction of PET data for partial volume effects in human cerebral cortex by MR imaging. J Comp Assist Tomogr 14:561-570

Meltzer C, Nichols T, Mintun M (1995): Effect of resolution on recovery of gray matter activity in FDG PET. J Nucl med 36:114P

Meltzer C, Zubieta J, Brandt J, Tune L, Mayberg H, Frost J (1996): Regional hypometabolism in Alzheimer disease as measured by PET following correction for effects of partial volume averaging. Neurology 47:454-461

Meltzer H (1990): Role of serotonin in depression. Ann NY Acad Sci 600:486-500

Middlemiss D, Palmer A, Edel N, Bowen D (1986): Binding of the novel serotonin agonist 8-hydroxy-2-(di-n-propylamino) tetralin in normal and Alzheimer brain. J Neurochem 46:993-996

Mueller-Gaertner H, Links J, Prince J, Bryan R, McVeigh E, Leal J, Davatzikos C, Frost J (1992): Measurement of radiotracer concentration in brain gray matter using positron emission tomography: MRI-based correction for partial volume effects. J Cereb Blood Flow Metab 12:571-583

Murphy D, DeCarli C, Schapiro M, Rapoport S, Horwitz B (1992): Age-related differences in volumes of subcortical nuclei, brain matter, and cerebrospinal fluid in healthy men as measured with magnetic resonance imaging. Arch Neurol 49:839-845

Myers BL, Badia P (1995): Changes in circadian rhythms and sleep quality with aging: Mechanisms and interventions. Neurosci Biobehav Rev 19:553-571

Newman ME, Shapira B, Lerer B (1992): Regulation of 5-hydroxytryptamine ${ }_{1 \mathrm{~A}}$ receptor function in rat hippocampus by short- and long-term administration of 5-hydroxytryptamine $\mathrm{A}_{\mathrm{A}}$ agonist and antidepressants. J Pharmacol Exp Ther 260:16-20

Nishizawa S, Benkelfat C, Young SN, Leyton M, Mzengeza S, Demontigny C, Blier P, Diksic M (1997): Differences between males and females in rates of serotonin synthesis in human brain. Proc Natl Acad Sci USA 94:53085313

Nordberg A (1992): Neuroreceptor changes in Alzheimer disease. Cerebrovasc Brain Metab Rev 4:303-328

Normile H, Altman H (1992): Effects of combined acetylcholinesterase inhibition and serotonergic receptor blockade on age-associated memory impairments in rats. Neurobiol Aging 13:735-740

Nybäck H, Nyman H, Blomqvist G, Sjögren I, Stone-Elander S (1991): Brain metabolism in Alzheimer dementia: Studies of ${ }^{11} \mathrm{C}$-deoxyglucose accumulation, CSF monoamine metabolites and neuropsychological test performance in patients and healthy subjects. J Neurol Neurosurg Psychiatry 54:672-678

Nyth A, Gottfries C (1990): The clinical efficacy of citalopram in treatment of emotional disturbances in dementia disorders. BR J Psychiatry 157:894-901

Osman S, Lundkvist C, Pike V, Halldin C, McCarron J, Swahn C-G, Ginovart N, Luthra S, Bench C, Grasby P, Wikström H, Barf T, Cliffe I, Fletcher A, Farde L (1996): Characterization of the radioactive metabolites of the 5-HT1A receptor radioligande, [O-methyl-11C]WAY-
100635, in monkey and human plasma by HPLC: Comparison of the behaviour of an identified radioactive metabolite with parent radioligand in monkey using PET. Nucl Med Biol 23:627-634

Owen F, Cross A, Crow T, Deakin J, Ferrier I, Lofthouse R, M $P$ (1983): Brain 5- $\mathrm{HT}_{2}$ receptors and suicide. Lancet ii:1256

Owen F, Chambers DR, Cooper SJ, Crow TJ, Johnson JA, Lofthouse R, Poulter M (1986): Serotonergic mechanisms in brains of suicide victims. Brain Res 362:185-188

Palacios J, Waeber C, Hoyer D, Mengod G (1990): Distribution of serotonin receptors. Ann NY Acad Sci 600:36-52

Palmer AM, Francis PT, Benton JS, Sims NR, Mann DMA, Neary D, Snowden JS, Bowen DM (1987a): Presynaptic serotonergic dysfunction in patients with Alzheimer's disease. J Neurochem 48:8-15

Palmer AM, Middlemiss DN, Bowen DM (1987b): $\left[{ }^{3} \mathrm{H}\right] 8-\mathrm{OH}-$ DPAT binding in Alzheimer's disease: An index of pyramidal cell loss? In Dourish C, Ahlenius A, Hutson P (eds), Brain 5- $\mathrm{HT}_{1 \mathrm{~A}}$ Receptors. Chichester, Ellis Horwood Ltd, pp 286-299

Palmer AM, Stratmann GC, Proctor AWP, Bowen DM (1988): Possible neurotransmitter basis of behavioral changes in Alzheimer's disease. Ann Neurol 23:616-620

Parmelee P, Katz I, Lawton M (1989): Depression among institutionalized aged: Assessment and prevalence estimation. J Gerontol 44:M22-M29

Paul S, Rehavi M, Skolnick P, Ballenger J, Goodwin F (1981): Depressed patients have decreased binding of tritiated imipramine to platelet serotonin "transporter." Arch Gen Psychiatry 38:1315-1317

Pauwels PJ (1997): 5HT $1 \mathrm{~B} / \mathrm{D}$ receptor antagonists. Gen Pharmacol 29:293-303

Peroutka SJ (1994): Molecular biology of serotonin (5-HT) receptors. Synapse 18:241-260

Perry EK, Tomlinson BE, Blessed G, Bergmann K, Gibson PH, Perry RH (1978): Correlation of cholinergic abnormalities with senile plaques and mental test scores in senile dementia. Br Med J 2:1457-1459

Perry E, Marshall E, Blessed G, Tomlinson B, Perry R (1983): Decreased imipramine binding in the brains of patients with depressive illness. Br J Psychiatry 142:188-192

Pike V, McCarron J, Lammertsma A, Osman S, Hume S, Sargent P, Bench C, Cliffe I, Fletcher A, Grasby P (1996): Exquisite delineation of $5-\mathrm{HT}_{1 \mathrm{~A}}$ receptors in human brain with PET and [carbonyl-11 C]WAY-100635. Eur J Pharmacol 301:R5-R7

Polinsky RJ, Noble J, Di Chiro G, Nee LE, Feldman RG, Brown RT (1987): Dominantly inherited Alzheimer disease: Cerebral glucose metabolism. J Neurol Neurosurg Psychiatry 50:752-757

Price J, Mathis C, Simpson N, Mahmood K, Mintun M (1996): Kinetic modeling of serotonin- ${ }_{1 \mathrm{~A}}$ binding in monkeys using $\left[{ }^{11} \mathrm{C}\right] W A Y 100635$ and PET. In Meyers R, Cunningham V, Bailey D, Jones T (eds), Quantification of Brain Function Using PET. San Diego, Academic Press, pp 257-261

Proctor AW, Francis PT, Stratmann GC, Bowen DM (1992): Serotonergic pathology is not widespread in Alzheimer patients without prominent aggressive symptoms. Neurochem Res 17:917-922 
Quirion R, Richard J (1987): Differential effects of selective lesions of cholinergic and dopaminergic neurons on serotonin-type 1 receptors in rat brain. Synapse 1:124130

Quirion R, Richard J, Dam TV (1985): Evidence for the existence of serotonin type-2 receptors on cholinergic terminals in rat cortex. Brain Res 333:345-349

Rapp P, Amaral D (1992): Individual differences in the cognitive and neurobiological consequences of normal aging. Trends Neurosci 15:340-345

Reiman E, Caselli R, Yun L, Chen K, Bandy D, Minoshima S, Thibodeau S, Osborne D (1996): Preclinical evidence of Alzheimer's disease in persons homozygous for the epsilon 4 allele for apolipoprotein E. N Engl J Med 334:752-758

Reinikainen KJ, Soininen H, Reikkinen PJ (1990): Neurotransmitter changes in Alzheimer's disease: Implications to diagnostics and therapy. J Neurosci Res 27:576586

Reynolds C, Kupfer D, Hoch C, Stack J, Houck P, Sewitch D (1986): Two-year follow-up of elderly patients with mixed depression and dementia. Clinical and electroencephalographic sleep findings. J Am Geriatr Soc 34:793799

Reynolds G, Arnold L, Rossor M, Iversen L, Mountjoy C, Roth M (1984): Reduced binding of $\left[{ }^{3} \mathrm{H}\right]$ Ketanserin to cortical $5-\mathrm{HT}_{2}$ receptors in severe dementia of the Alzheimer type. Neurosci Lett 44:47-51

Richter-Levin G, Segal M (1990): Age-related cognitive deficits in rats are associated with a combined loss of cholinergic and serotonergic functions. Ann NY Acad Sci 600:254-257

Riekkinen M, Tolonen R, Riekkinen P Jr (1994): Interaction between $5-\mathrm{HT}_{1 \mathrm{~A}}$ and nicotinic cholinergic receptors in the regulation of water maze navigation behavior. Brain Res 649:174-180

Rinaldi-Carmona M, Congy C, Simiand J, Oury-Donat F, Soubrie P, Breliere JC, Le Fur G (1993): Repeated administration of SR 46349B, a selective 5-hydroxytryptamine $_{2}$ antagonist, up-regulates 5-hydroxytryptamine receptors in mouse brain. Mol Pharmacol 43:84-89

Robinson D, Rickels K, Feighner J, Fabre L, Gammans R, Shrotriya R, Alms D, Andary J, Messina M (1990): Clinical effects of the 5- $\mathrm{HT}_{1 \mathrm{~A}}$ partial agonists in depression: A composite analysis of buspirone in the treatment of depression. J Clin Psychopharmacol 10:67S-76S

Robinson SE (1983): Effect of specific serotonergic lesions on cholinergic neurons in the hippocampus, cortex and striatum. Life Sci 32:345-353

Robson L, Gower A, Kendall D, Marsden C (1993): Agerelated behavioural, neurochemical and radioligand binding changes in the central 5-HT system of SpragueDawley rats. Psychopharmacology 113:274-281

Sadzot B, Lemaire C, Maquet P, Salmon E, Plenevaux A, Degueldre C, Hermanne J, Guillaume M, Cantineau R, Comar D, Franck G (1995): Serotonin 5HT 2 receptor imaging in the human brain using positron emission tomography and a new radioligand, [81F]altanserin: Results in young normal controls. J Cereb Blood Flow Metab 15:787-797

Salmon E, Maquet P, Sadzot B, Degueldre C, Lemaire C,
Franck G (1991): Decrease of frontal metabolism demonstrated by positron emission tomography in a population of healthy elderly volunteers. Acta Neurol Belg 91:288-295

Saudou F, Hen R (1994): 5-hydroxytryptamine receptor subtypes in vertebrates and invertebrates. Neurochem Int 25:503-532

Schneider LS, Severson J, Chui H, Pollock V, Sloane R, Fredrickson E (1988): Platelet H3-imipramine binding in Alzheimer's disease patients with agitation and delusions. Psychiatry Res 25:311-322

Schone W, Ludwig M (1993): A double-blind study of paroxetine compared with fluoxetine in elderly patients with major depression. J Clin Psychopharmacol 13(Suppl 2):34S-39S

Seab JP, Jagust WP, Wong STS, Roos MS, Reed BR, Budinger TF (1988): Quantitative NMR measurements of hippocampal atrophy in Alzheimer's disease. Magn Reson Med 8:200-208

Shapira B, Lerer B, Kindler S, Lichtenberg P, Gropp C, Cooper T, Calev A (1992): Enhanced serotonergic responsivity following electroconvulsive therapy in patients with major depression. Br J Psychiatry 160:223-229

Sharpley AL, Elliott JM, Attenburrow MJ, Cowen PJ (1994): Slow wave sleep in humans: Rose of $5-\mathrm{HT}_{2 \mathrm{~A}}$ and $5-\mathrm{HT}_{2 \mathrm{C}}$ receptors. Neuropharmacology 33:467-471

Shefer VF (1972): Absolute numbers of neurons and thickness of the cerebral cortex during aging, senile and vascular dementia, and Pick's and Alzheimer's diseases. Neurosci Behav Physiol 6:319-324

Shih J, Young H (1978): The alteration of serotonin binding sites in aged human brained. Life Sci 23:1441-1448

Shuttleworth EC, Huber SJ, Paulson GW (1987): Depression in patients with dementia of the Alzheimer type. J Natl Med Assoc 79:733-736

Small G, Mazziotta J, Collins M (1995): Apolipoprotein E type 4 allele and cerebral glucose metabolism in relatives at risk for familial Alzheimer disease. JAMA 273:942-947

Sparks D (1989): Aging and Alzheimer's disease. Altered cortical serotonergic binding. Arch Neurol 46:138-140

Sparks D, Markesbery W, Slevin J (1986): Alzheimer's disease: Monoamines and spiperone binding reduced in nucleus basalis. Ann Neurol 19:602-604

Staner L, Kempanaers C, Simonnet M-P, Fransolet L, Mendlewicz J (1992): 5- $\mathrm{HT}_{2}$ receptor antagonism and slowwave sleep in major depression. Acta Psychiatr Scand 86:133-137

Stanley M, Mann J (1983): Increased serotonin-2 binding sites in the frontal cortex of suicide victims. Lancet i:214-216

Stanley M, Virgilio J, Gershon S (1982): Tritiated imipramine binding sites are decreased in the frontal cortex of suicides. Science 216:1337-1339

Stockmeier C, Dilley G, Shapiro L, Overholser J, Thompson P, Meltzer H (1996): Serotonin receptors in suicide victims with major depression. Neuropsychopharmacology 16:162-173

Strosznajder J, Samochocki M, Duran M (1994): Aging diminishes serotonin-stimulated arachidonic acid uptake and cholinergic receptor-activated arachidonic acid release in rat brain cortex membrane. J Neurochem 62:1048-1054 
Suehiro M, Scheffel U, Dannals R, Ravert H, Ricaurte G, Wagner H Jr (1993a): A PET radiotracer for studying serotonin uptake sites: Carbon-11-McN-5652Z. J Nucl Med 34:120-127

Suehiro M, Scheffel U, Ravert H, Dannals R, Wagner H Jr (1993b): $[11 C](+) M c N 5652$ as a radiotracer for imaging serotonin uptake sites with PET. Life Sci 53:883-892

Szabo Z, Kao P, Scheffel U, Suehiro M, Mathews W, Ravert H, Musachio J, Marenco S, Kim S, Ricaurte G, Wong D, Wagner H, Dannals R (1995a): Positron emission tomography imaging of serotonin transporters in the human brain using $[11 \mathrm{C}](+) \mathrm{McN} 5652$. Synapse 20:37-43

Szabo Z, Scheffel U. Suehiro M, Dannals R, Kim S, Ravert H, Ricaurte G, Wagner H (1995b): Positron emission tomography of 5-HT transporter sites in the baboon brain with $\left.{ }^{[11} \mathrm{C}\right] \mathrm{McN} 5652$. J Cereb Blood Flow Metab 15:798-805

Takada H, Nagata K, Hirata Y, Satoh Y, Watahiki Y, Sugawara J, Yokoyama E, Kondoh Y, Shishido F, Inugami A, Fujita H, Ogawa T, Murakami M, Iida H, Kanno I (1992): Age-related decline of cerebral oxygen metabolism in normal population detected with positron emission tomography. Neurol Res 14(Suppl.):128-131

Tejani-Butt S, Yang J, Pawlyk A (1995): Altered serotonin transporter sites in Alzheimer's disease raphe and hippocampus. Neuro Report 6:1207-1210

Teri L, Reifler B (1987): Depression and dementia. In Carstensen L, Edelstein B (eds), Handbook of Clinical Gerontology. New York, Pergamon Press, pp 112-119

Terry RD, Peck A, DeTeresa R, Schechter R, Horoupian DS (1981): Some morphometric aspects of the brain in senile dementia of the Alzheimer type. Ann Neurol 10:184-192

Tork I (1990): Anatomy of the serotonergic system. Ann NY Acad Sci 600:9-35

Tsuiki K, Mück-Seler C, Diksic M (1995a): Autoradiographic evaluation of the influence of hypothalamic 5, 7-dihydroxytryptamine lesion on brain serotonin synthesis. Biochem Pharmacol 49:633-642

Tsuiki K, Yamamoto Y, Diksic M (1995b): Effect of acute fluoxetine treatment on the brain serotonin synthesis as measured by the $\delta$-methyl-L-tryptophan autoradiographic method. J Neurochem 65:250-256
Venero J, de la Roza C, Machado A, Cano J (1993): Agerelated changes on monoamine turnover in hippocampus of rats. Brain Res 631:89-96

Vizi ES, Harsing LG, Zsilla G (1981): Evidence of the modulatory role of serotonin in acetylcholine release from striatal interneurons. Brain Res 212:89-99

Whitehouse PJ, Struble RG, Hedreen JC, Clark AW, Price DL (1985): Alzheimer's disease and related dementias: Selective involvement of specific neuronal systems. CRC Crit Rev Clin Neurobiol 1:319-339

Wiernsperger N (1990): Serotonin 5- $\mathrm{HT}_{2}$ receptors and brain circulation. J Cardiovasc Pharmacol 16:S20-S24

Wong D, Wagner HJ, Dannals R, Links J, Frost J, Ravert H, Wilson A, Rosenbaum A, Gjedde A, Douglass K, Petronis J, Folstein M, Toung J, Burns H, Kuhar M (1984): Effects of age on dopamine and serotonin receptors measured by positron tomography in the living human brain. Science 226:1393-1396

Yamaguchi T, Yamagata A (1991): Serotonergic ligand binding in aging brain of experimental animals. Neurochem Res 16:469-473

Yoshii F, Barker W, Chang J, Loewenstein D, Apicella A, Smith D, Boothe T, Ginsberg M, Pascal S, Duara R (1988): Sensitivity of cerebral glucose metabolism to age, gender, brain volume, brain atrophy, and cerebrovascular risk factors. J Cereb Blood Flow Metab 8:654-661

Zhang L, Ma W, Barker J, Rubinow D (1994): Sexual differences in mRNA expression and binding distribution of $5-\mathrm{HT}_{1 \mathrm{~A}}$ and $5-\mathrm{HT}_{2}$ receptors in rat hippocampus. Soc Neurosci Abstr 21:1548

Zola-Morgan S, Squire L, Rempel N, Clower R, Amaral D (1992): Enduring memory impairment in monkeys after ischemic damage to the hippocampus. J Neurosci 12: 2582-2596

Zubenko G, Moossy J, Martinez A, Rao G, Classen D, Rosen J, Kopp U (1991): Neuropathologic and neurochemical correlates of psychosis in primary dementia. Arch Neurol 48:619-624

Zweig R, Swiergiel T, Steele C, Price D, Ross C (1995): The dorsal raphe and depression in Alzheimer's disease. Soc Neurosci Abstr 21 (Part 3): 1977 